Review Article

\title{
Medicinal Uses, Phytochemistry, and Pharmacological Activities of Quercus Species
}

\author{
Mehdi Taib $\mathbb{D}^{1}{ }^{1}$ Yassine Rezzak, ${ }^{1}$ Lahboub Bouyazza, ${ }^{1}$ and Badiaa Lyoussi $\mathbb{D}^{2}$ \\ ${ }^{1}$ Laboratory of Renewable Energy, Environment and Development, Hassan 1st University Faculty of Science and Technology, \\ P.O. Box 577, Settat, Morocco \\ ${ }^{2}$ Laboratory of Natural Substances, Pharmacology, Environment, Modeling, Health and Quality of Life (SNAMOPEQ), \\ University of Sidi Mohamed Ben Abdellah, Fez 30 000, Morocco \\ Correspondence should be addressed to Mehdi Taib; m.taib@uhp.ac.ma and Badiaa Lyoussi; lyoussi@gmail.com
}

Received 3 March 2020; Accepted 5 June 2020; Published 31 July 2020

Academic Editor: Filippo Fratini

Copyright (c) 2020 Mehdi Taib et al. This is an open access article distributed under the Creative Commons Attribution License, which permits unrestricted use, distribution, and reproduction in any medium, provided the original work is properly cited.

\begin{abstract}
Quercus species, also known as oak, represent an important genus of the Fagaceae family. It is widely distributed in temperate forests of the northern hemisphere and tropical climatic areas. Many of its members have been used in traditional medicine to treat and prevent various human disorders such as asthma, hemorrhoid, diarrhea, gastric ulcers, and wound healing. The multiple biological activities including anti-inflammatory, antibacterial, hepatoprotective, antidiabetic, anticancer, gastroprotective, antioxidant, and cytotoxic activities have been ascribed to the presence of bioactive compounds such as triterpenoids, phenolic acids, and flavonoids. This paper aimed to provide available information on the medicinal uses, phytochemicals, and pharmacology of species from Quercus. However, further investigation is needed to fully clarify the mode of action of its bioactive compounds and to evaluate in vivo chronic toxicity, before exploring their potential use as a supplement in functional foods and natural pharmaceutics.
\end{abstract}

\section{Introduction}

Since primitive times, humans have been using plants for their essential requirements such as food and medicine. These plants have been used in traditional medicine in order to cure and prevent various human disorders. The important advantage for therapeutic uses of the plants includes their safety, effectiveness, economic feasibility, and ease of availability [1]. Recently, the global demand for medicinal plant products has increased from USD 19.6 billion in 1996 to USD 24.2 billion in 2002 and is projected to reach USD 5 trillion by 2050 [2]. Among a number of medicinal plants, species belonging to the genus Quercus are widely used in traditional medicine. This genus belongs to the family Fagaceae. It comprises 600 species worldwide, which often differ in their flowering and fruiting dynamics and by the maturation index [3]. Species of the Quercus genus are mainly distributed in the basin Mediterranean (Portugal, Spain, Algeria France,
Italy, Tunisia, and Morocco), Asia, and North America. The extraordinary species diversity reported in America and Asia together is with the highest diversity at $15-30^{\circ} \mathrm{N}$ in Mexico and East Asia [4, 5]. Europe exhibits lower species richness (up to 30 species), but the genus is nearly as widespread there as it is in North America and East Asia, as a limited number of European species have expanded across the continent [6].

Species of the genus Quercus are important medicinal plants. Over the centuries, these species have been used in folk medicine to treat various diseases Table 1. Indigenous peoples, in many areas of the world, use them as antiseptics and to treat gastrointestinal tract (GIT) disorders such as diarrhea and hemorrhoids. The bark of the oak has much importance and is used extensively in medicine as an antiseptic and hemostatic, used to cure toothache and gastropathies, and also used as pacifying agents in inflammation and as healing agents in burn [34, 37, 38]. However, the resin of Quercus leucotrichophora A. Camus 
TABLe 1: Medicinal uses of some Quercus species.

\begin{tabular}{|c|c|c|c|}
\hline Species & Part & Medicinal use & Reference \\
\hline Quercus alba $L$. & Bark & Used as astringent, venotonic, and hemostatic & [7] \\
\hline Quercus acutissima Carr & Acorn & $\begin{array}{c}\text { Treat colitis, stomatitis, labor pains, obesity laryngopharyngitis diseases, } \\
\text { astrictiona, diarrheaa, and furuncles }\end{array}$ & {$[8,9]$} \\
\hline Quercus brantii Lindl & $\begin{array}{l}\text { Leaves } \\
\text { Bark } \\
\text { Acorn } \\
\text { Gall }\end{array}$ & $\begin{array}{c}\text { Astringent effects, treatment of tonsillitis, and throat infections } \\
\text { Chronic skin diseases such as eczema and varicose veins } \\
\text { Diarrhea, internal enzymes, indigestion, stomach pain, anemia, rickets, and } \\
\text { tuberculosis } \\
\text { Stomach tonic, astringent, and bleeding stopper } \\
\text { Diarrhea, coughing, mouth ulcer, and stomach ulcer }\end{array}$ & {$[10-13]$} \\
\hline Quercus cerris $L$. & $\begin{array}{l}\text { Acorn } \\
\text { Bark }\end{array}$ & $\begin{array}{l}\text { Beverage, throat inflammation, cicatrizing for wounds of livestock, tea for female } \\
\text { disorders, ointment for wounds, diaphoretic, hemorrhoids, intestinal } \\
\text { inflammation, psoriasis, thinness, and fodder }\end{array}$ & [14-18] \\
\hline Quercus coccifera $L$. & $\begin{array}{l}\text { Leaves } \\
\text { Gall } \\
\text { Acorn }\end{array}$ & $\begin{array}{l}\text { Fodder, wild vegetables, astringent enuresis, metritis, gingivitis, dermatitis, } \\
\text { diarrhea, vaginal diseases, cough, and hypertension }\end{array}$ & [19-21] \\
\hline & $\begin{array}{l}\text { Acorn } \\
\text { Leaves }\end{array}$ & $\begin{array}{l}\text { Serve as brain, sexual tonic, cleaning teeth eradication of gonorrhea, urinary tract } \\
\text { infections in district Swat }\end{array}$ & \\
\hline Quercus dilatata & $\begin{array}{l}\text { Bark } \\
\text { Wood }\end{array}$ & $\begin{array}{l}\text { Sore mouth throat in Lawat district astringent, diuretic, diarrhea, indigestion and } \\
\text { asthma in Poonch Valley, clean foul sores }\end{array}$ & {$[22-24]$} \\
\hline Quercus dentata Thunb & $\begin{array}{l}\text { Flowers } \\
\text { Gall } \\
\text { Gall }\end{array}$ & $\begin{array}{c}\text { Treatment of diarrhea, menorrhagia, and gastrointestinal } \\
\text { Dysentery, diarrheaa }\end{array}$ & {$[8]$} \\
\hline Quercus ilex $L$. & $\begin{array}{c}\text { Roasted } \\
\text { seeds }\end{array}$ & Used as aesthetic hair, gingiva, tonic drink coffee, fodder & {$[25,26]$} \\
\hline Quercus incana Roxb. & $\begin{array}{l}\text { Leaves } \\
\text { Bark } \\
\text { Acorn } \\
\text { Wood }\end{array}$ & $\begin{array}{l}\text { Used as astringent diuretic, antidiarrheal agent, treatment asthma. Antipyretic, } \\
\text { antirheumatism, antidiabetic, and antiarthritic, gastrointestinal disorders, } \\
\text { inflammations of the oral, genital, anal mucosa inflammation of the skin, } \\
\text { skeletomuscular problems and antiarthritic purposes }\end{array}$ & [27-29] \\
\hline Quercus infectoria-Olivier. & Gall & $\begin{array}{l}\text { Used as astringent, diabetes disease, restore the elasticity of the uterine wall, } \\
\text { inflammatory disorders, wound infections after childbirth, treatment of toothache, } \\
\text { gingivitis, skin disorder, antiseptic, antistomatitis, deodorant, derivative, } \\
\text { desiccant, expectorant styptic, tonic, tonic to teeth and wound healing }\end{array}$ & {$[18,30-32]$} \\
\hline $\begin{array}{l}\text { Quercus leucotrichophora } \\
\text { A. Camus. }\end{array}$ & $\begin{array}{l}\text { Acorn } \\
\text { Leaves } \\
\text { Bark }\end{array}$ & $\begin{array}{c}\text { Treatment of urinary infection, cure toothache and piles, astringent, diarrhea, } \\
\text { stomach ache cure, gonorrhea, asthma, hemorrhages, dysentery, gonorrheal } \\
\text { digestive disorders, stomach pain, diuretic, urinary disorder, snake bite, check } \\
\text { dysentery }\end{array}$ & [33-35] \\
\hline Quercus robur $L$. & $\begin{array}{l}\text { Leaves } \\
\text { Bark }\end{array}$ & Diabetes, diarrhea & {$[36]$} \\
\hline
\end{tabular}

is used to cure gonorrhea, asthma, hemorrhages, diarrhea, and dysentery [34]. Powder of gallnuts of Q. infectoria is used to restore the elasticity of the uterine wall, as well as to treat aphthous ulcers $[31,39]$. The fruit (acorn) of the Quercus species is considered as a nutritionally rich source of energy (source of carbohydrates, proteins, and fat), justifying their use as food or ingredient food for thousands of years in the human diet such as in bread production or as an ingredient for making coffee [40-42]. The acorns of the various species of oak are widely used in curing diarrhea, laryngopharyngitis diseases, menorrhagia, obesity, and stomach ulcers [8,9].

Pharmacological effect reported for the Quercus genus plant includes antioxidant, antimicrobial, anti-inflammatory, antidiabetic, hepatoprotective, gastrointestinal disorder, skin disorder, antiobesity, anticancer, and neurogenerative effect [43-49]. All mentioned effects are attributed to the specific chemical composition, comprised mainly of triterpenoids, flavonoids, and tannins.
As an example, Endo et al. [50] investigated the antitoxoplasma effect of the Quercus crispula Blume outer bark. The authors identified three pentacyclic triterpenoids, namely, 29-norlupane-3,20-dione, oleanolic acid acetate, and ursolic acid acetate, and concluded that these compounds exhibited notable activities against the Toxoplasma gondii parasite. Moreover, Lei et al. [45] successfully isolated new triterpenoids, which were identified as ursane, oleanane, and lupinane type and were found to be associated with the antineuroinflammatory activity. Even so, numerous studies describing the bioactivities of acorns are focused on their strong antioxidant activity, which are believed to be useful in treating oxidation-associated diseases such as diabetes, cancer, and cardiovascular and inflammatory diseases [41, 51-53].

The purpose of this review is to provide up-to-date information on traditional medicinal uses, phytochemistry, and pharmacological activities of Quercus species in 
order to explore their therapeutic potential and evaluate future research opportunities.

\section{Quercus Genus}

The oak family (Quercus spp.) plays a major ecological role in terms of sheer abundance of standing biomass [54]. The genus Quercus is among the most widespread and speciesrich tree genera in the northern hemisphere [6]. The highest diversity is exhibited in Mexico and East Asia [4, 5]. Europe exhibits lower species richness (up to 30 species), but the genus is nearly as widespread there as it is in North America and East Asia, as a limited number of European species have expanded across the continent [6]. Quercus spp. (oak) represent an important genus of the Fagaceae family which consists of 600 species worldwide, which includes monecious, deciduous, evergreen trees, and rarely shrubs. The genus Quercus has long been considered one of the most imperative clades of all woody plants in terms of species diversity, ecological dominance, and economic value. The leaves of many oak species are conspicuously lobed, but some species reveal variations in shape from small to large and pointed. Oaks are considered monecious plants, having separate male and female flowers on a single tree. Generally, the male flowers occur in clusters but sometimes are organized in a form called catkin. The female flowers are borne on solitary spikes in the axils of leaves or bracteoles of the new growth [55]. The flowers mostly ripen in the sepals, which later mature into the fruit. The fruit identified as acorn, which is a nut, is characterized by the absence of an endosperm and the presence of an achlorophyllous embryo.

\section{Medicinal Uses of Some Species from Quercus}

Quercus species have long been used as traditional medicine in several countries and tribes. Almost all parts of the plants including fruit, bark, and leaves were documented to display a broad range of medicinal properties (Table 1). Indigenous peoples, in many areas of the world use them as antiseptics and to treat gastrointestinal tract (GIT) disorders such as diarrhea and hemorrhoids (Table 1). It is widely used to treat gonorrhea, gastritis, asthma, pyrexia, Parkinson's disease, and hepatoprotective diseases [56], and also hemorrhoid, varicose veins, diarrhea, gastric ulcers, and superficial injuries [57].

The bark of the oak has much importance and is used extensively in medicine as an antiseptic and an energizer. The decoctions from the barks of Q. robur and Q. petraea were recognized to have anti-inflammatory, antibacterial, and antihemorrhagic activities [58]. Indeed, it has been suggested for the treatment of patients with high levels of blood sugar [59] and treatment of sore throat [24]. The leaves of $Q$. virginiana have been used as antimicrobial agent. As well as, can be employed for the treatment of gastrointestinal disorders $[60,61]$. The galls of $Q$. infectoria are used to restore the elasticity of the uterine wall, as well as to treat many inflammatory disorders [31]. Also, they are used in Malay traditional medicine commonly to treat wound infections after childbirth [32]. In India, they are employed traditionally as dental applications such as that in treatment of toothache and gingivitis. In Asia, it has been widely used for the treatment of infection diseases, skin disorders, and inflammatory ailments [39]. The traditional system of medicine is an integral part of Kumaun and Garhwal regions of Uttarakhand, and others states in India used Quercus leucotrichophora A. Camus for treatment of urinary infection [34], stomach pain [35], gonorrhea, asthma, hemorrhages, diarrhea, dysentery [33], urinary disorder [62], and diuretics [63]. Besides, in Korean medicine folk, they are widely used for their dysentery, antidiarrhea, and antidermatitic proprieties [64].

The fruit (acorn) of oak species is a rich source of energy, containing high amounts of carbohydrates, proteins, amino acids, lipids, and sterols. The earliest evidence of acorns as a foodstuff was dated to the late Mesolithic era and found in Western Europe. In the North American West Coast, acorns made up more than half of the diet of native peoples [65]. The fruit from Quercus humilis Mill are mainly consumed roasted, raw, or as an ingredient for making coffee only in particular areas [40]. In the northeast of the Iberian Peninsula, the fruit of holm oak Q. ilex subsp. locally known as kiskurras were used raw, boiled, roasted, like coffee, or transformed into flour. In addition, its flour was mixed with cereal grain flour to make bread [66]. Similarly, in Serbia, Quercus cerris seeds are widely used for bread production [16]. Also, the oil obtained from the acorn has been consumed by native peoples for hundreds of years. It is a nutritious cooking oil comparable to those obtained from peanut, cotton, olive, and avocado [52, 65].

\section{Phytochemicals}

The Quercus genus contains various classes of compounds such as glycosides, terpenoids, flavonoids, phenolic acids, fatty acids, sterols, and tannins. The polyphenols isolated from the Quercus genus are reported in Table 2. Despite the phylogenetic variability, phenolic acids (particularly, gallic and ellagic acids and their derivatives), flavonoids (particularly flavan-3-ol), and tannins are abundant in all the species of Quercus [52]. To date, seven compounds were isolated from Quercus gilva Blume (QGB) and identified as picraquassioside $\mathrm{D}$, quercussioside, (+)-lyoniresinol-90 $\alpha$ - $O-\beta$-D-xylopyranoside, (+)-catechin, (-)-epicatechin, procyanidin $\mathrm{B} 3$, and procyanidin B4. The presence of these compounds suggests that QGB could be used in the treatment of urolithiasis [80]. In addition, Gul et al. [78] successfully isolated a new compound, quercuschin, with six other compounds which were identified as quercetin, methyl gallate, gallic acid, betulinic acid, (Z)-9-octadecenoic acid methyl ester, and $\beta$-sitosterol glucoside from $Q$. incana. Indeed, the compounds such as eupatorin $\left(5,3^{\prime}\right.$-dihydroxy- $6,7,4^{\prime}$ trimethoxyflavone), cirsimaritin $\left(4^{\prime}, 5, \quad\right.$-dihydroxy-6,7dimethoxyflavone), betulin (lup-20(29)-ene-3, 28-diol), and $\beta$-amyrin acetate (12-oleanen-3yl acetate) were also observed in the leaves of Quercus incana [29].

The main compound found in the methanol leaves extract of Quercus suber was gentisic acid [84]. However, 
TABle 2: Polyphenolic compounds in Quercus species.

\begin{tabular}{|c|c|c|c|}
\hline Compound isolated & Chemical structure & Species & Reference \\
\hline Gallic acid & 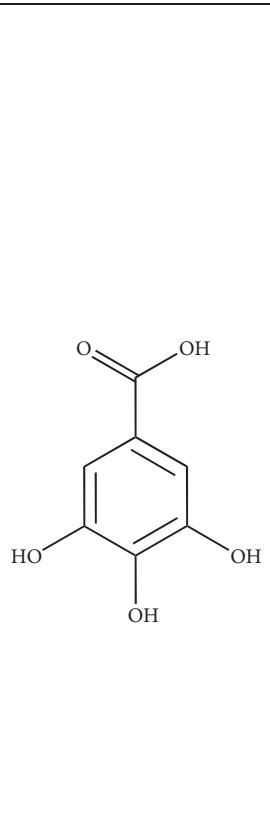 & 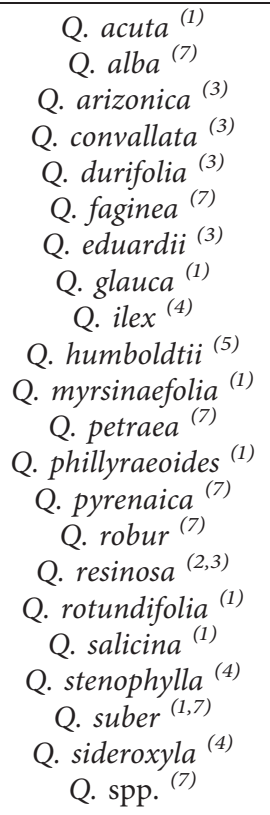 & $\begin{array}{l}\text { (1) }[67] \\
(2)[47] \\
(3)[68] \\
(4)[69] \\
(5)[70] \\
(6)[71] \\
(7)[72]\end{array}$ \\
\hline Quinic acid & & Q. suber & {$[73]$} \\
\hline Gentisic acid & & $\begin{array}{l}{\text { Q. } \text { acuta }^{(1)}}^{(1)} \\
{\text { Q. } \text { glauca }^{(1)}}^{(1)} \\
\text { Q. phillyraeoides } \\
\text { Q. salicina } \\
\text { Q. spp. }\end{array}$ & $\begin{array}{l}\text { (1) }[67] \\
\text { (2) }[72]\end{array}$ \\
\hline Chlorogenic acid & & 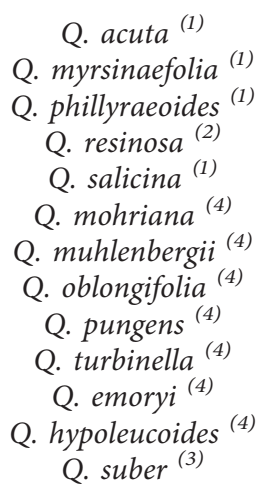 & $\begin{array}{l}\text { (1) }[67] \\
(2)[47] \\
(3)[71] \\
\text { (4) }[74]\end{array}$ \\
\hline Caffeic acid & & 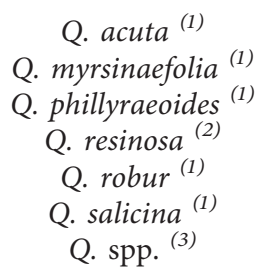 & $\begin{array}{l}\text { (1) }[67] \\
\text { (2) }[47] \\
\text { (3) }[72]\end{array}$ \\
\hline
\end{tabular}


TABle 2: Continued.

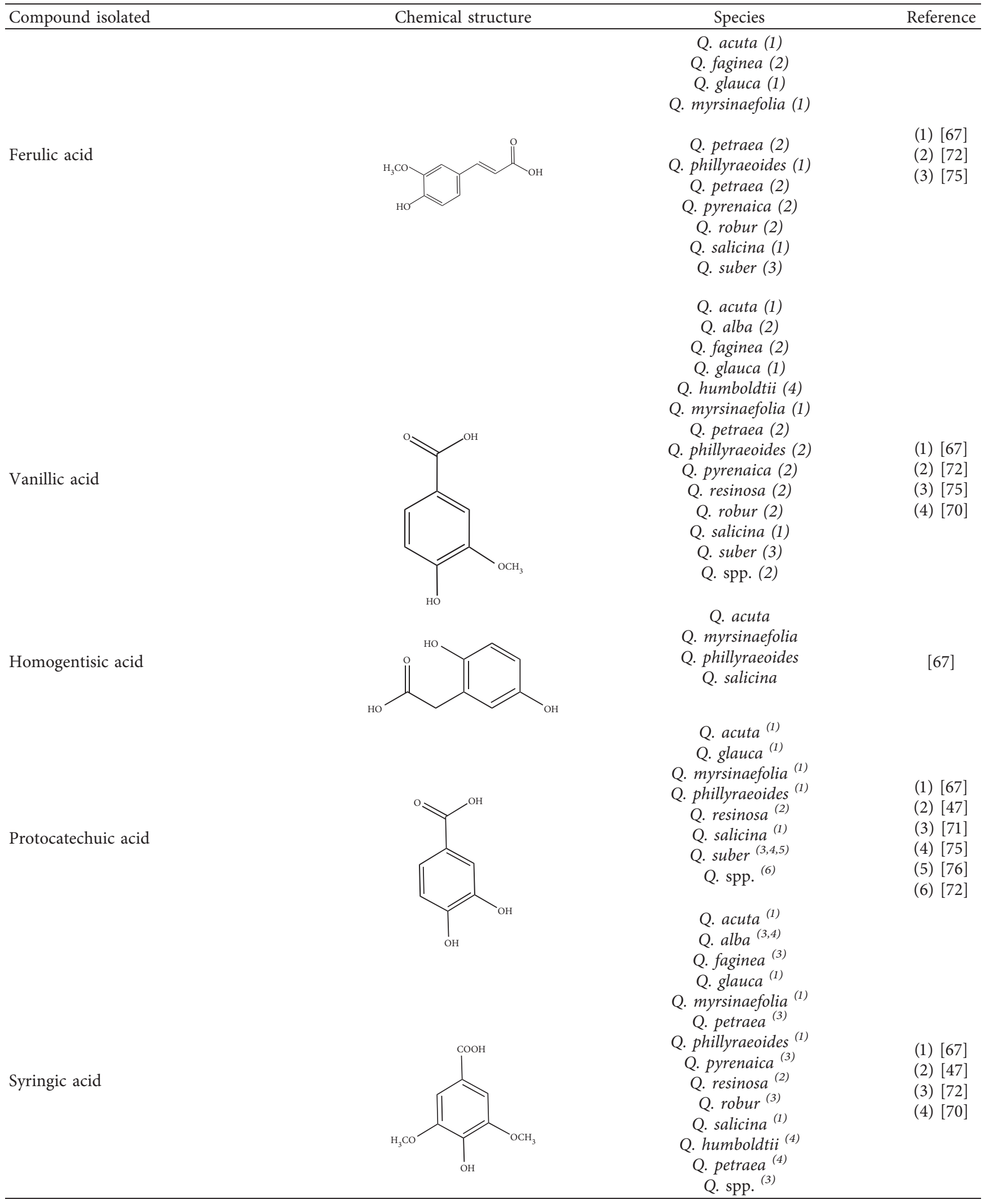


TABle 2: Continued.

\begin{tabular}{|c|c|c|c|}
\hline Compound isolated & Chemical structure & Species & Reference \\
\hline Galloylquinic acid & & $\begin{array}{l}\text { Q. emoryi } \\
\text { Q. hypoleucoides }\end{array}$ & {$[74]$} \\
\hline Vanillin & & 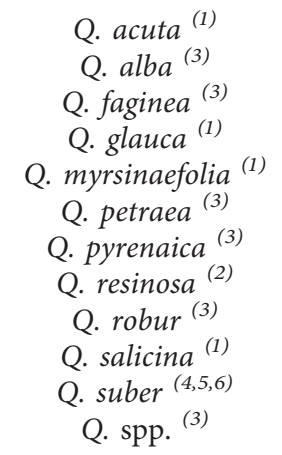 & $\begin{array}{l}\text { (1) }[67] \\
(2)[47] \\
(3)[72] \\
(4)[75] \\
(5)[73] \\
(6)[71]\end{array}$ \\
\hline Kaempferol & & $\begin{array}{l}\text { Q. acutaQ. } \text { glauca }^{(1)} \\
\text { Q. myrsinaefolia } \\
\text { Q. phillyraeoides }^{(1)} \\
\text { Q. salicina }^{(1)} \\
\text { Q. stenophylla }\end{array}$ & $\begin{array}{l}\text { (1) }[67] \\
\text { (2) }[77]\end{array}$ \\
\hline Quercetin & & 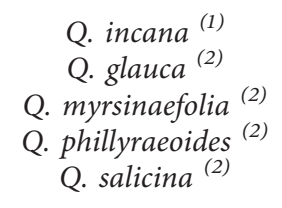 & $\begin{array}{l}\text { (1) }[78] \\
\text { (2) }[67]\end{array}$ \\
\hline Naringenin & $\mathrm{OH}$ & 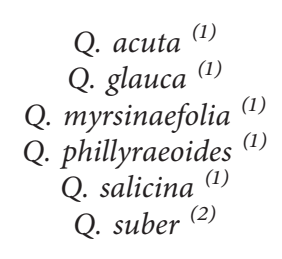 & $\begin{array}{l}\text { (1) }[67] \\
\text { (2) }[73]\end{array}$ \\
\hline Acutissimin A & & $\begin{array}{c}\text { Q. arizonica } \\
\text { Q. gambelii } \\
\text { Q. grisea } \\
\text { Q. havardii } \\
\text { Q. mohriana } \\
\text { Q. muhlenbergii } \\
\text { Q. oblongifolia } \\
\text { Q. pungens } \\
\text { Q. rugosa } \\
\text { Q. turbinella }\end{array}$ & {$[74]$} \\
\hline
\end{tabular}


TABle 2: Continued.

\begin{tabular}{|c|c|c|c|}
\hline Compound isolated & Chemical structure & Species & Reference \\
\hline Epicatechin & & $\begin{array}{l}\text { Q. convallata } \\
\text { Q. resinosa } \\
\text { Q. gilva }\end{array}$ & {$[47,79,80]$} \\
\hline Castalagin & $\mathrm{OH}$ & 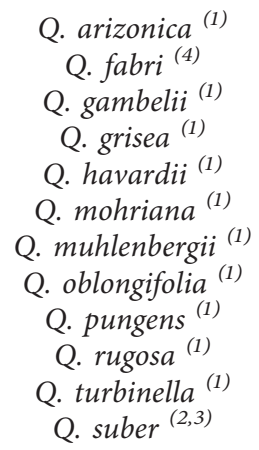 & $\begin{array}{l}\text { (1) }[74] \\
(2)[71] \\
(3)[16] \\
\text { (4) }[81]\end{array}$ \\
\hline Gallocatechin & & 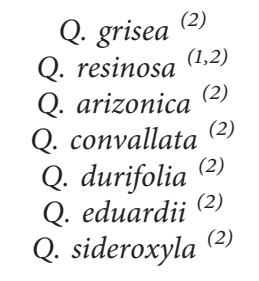 & $\begin{array}{l}\text { (1) }[47] \\
\text { (2) }[68]\end{array}$ \\
\hline Epicatechin gallate & & 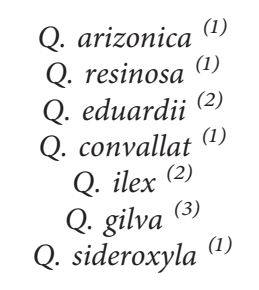 & $\begin{array}{l}\text { (1) }[68] \\
\text { (2) }[82] \\
\text { (3) }[80]\end{array}$ \\
\hline Epigallocatechin-3-gallate & & $\begin{array}{c}\text { Q. }^{\text {.lex }}{ }^{(1)} \\
\text { Q. }^{(2)} \text { grisea }^{(2)} \\
\text { Q. resinosa } \\
\text { Q. } \text { arizonica }^{(2)} \\
\text { Q. convallata } \\
\text { (2) }\end{array}$ & $\begin{array}{l}\text { (1) }[82] \\
\text { (2) }[68]\end{array}$ \\
\hline Eupatorin & & Q. incana & {$[29]$} \\
\hline
\end{tabular}


TABle 2: Continued.

Compound isolated Chemical structure Species Reference

Cirsimaritin<smiles>COc1cc2oc(-c3ccc(O)cc3)cc(=O)c2c(O)c1O</smiles>

Q. incana

Methyl gallate<smiles>COC(=O)c1cc(O)c(O)c(O)c1</smiles>

Picraquassioside D

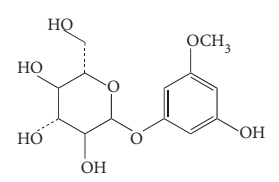

Quercussioside

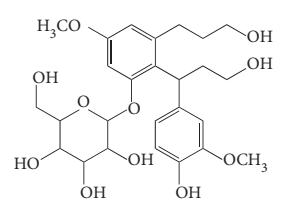

Q. incana

Procyanidin B3

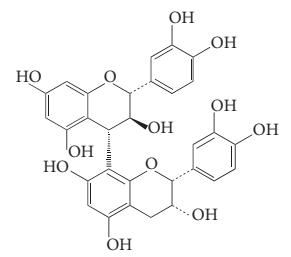

Procyanidin B4

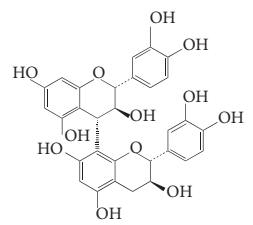

$$
\text { Q. gilva }
$$

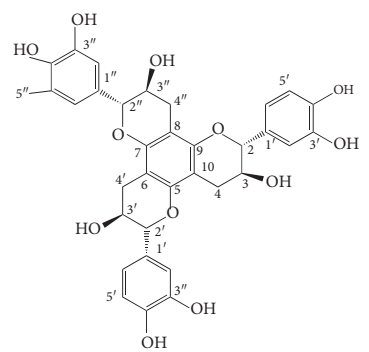

Q. incana

\section{Quercuschin}

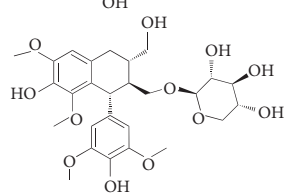

$$
\begin{aligned}
& \text { Q. coccifera } \\
& \text { Q. gilva }
\end{aligned}
$$

Lyoniresinol-9-O- $\beta$-xylopyranoside

Polydatin

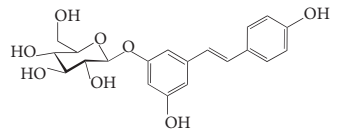

Q. coccifera 
another study performed by Yin et al. [85], who analyzed the $50 \%$ ethanol crude extract of Mongolian oak cups, demonstrated that ellagic acid (EA) and kaempferol derivatives were the main phenolic components. Moreover, Sari et al. [83] reported five compounds, which are lyoniresinol-9-O- $\beta$-xylopyranoside, lyoniresinol- 9-O$\beta$-glucopyranoside, (-)-8-chlorocatechin, polydatin, and cocciferoside that occur in the Quercus coccifera bark.

Using advanced spectroscopic techniques, Indrianingsih et al. [86] isolated catechin, epicatechin, and tiliroside from Q. gilva. The tiliroside found in $Q$. gilva can inhibit $\alpha$-glucosidase activity. Flavonoids are also found to be important bioactive compounds of Quercus leaves. $\mathrm{Xu}$ et al. [87] conducted a study on acorn leaves (Quercus liaotungensis) and isolated one new flavonoid glycoside, namely, 2,3-diol acetonide-3-O- $\alpha$-L-rhamnopyranoside-kaempferol, and 25 known polyphenolics. Recently, a study carried out on the infusion of the leaves of the six different species of Quercus revealed the presence of 7 flavan-3-ols, 2 flavonols, 18 flavonols/flavanone glycosides, 1 flavanone, 1 flavone, and 4 other unknown compounds. In this context, the presence of 4 procyanidin dimers in infusions was also documented [79].

Triterpenoids have also been isolated from the species of Quercus. Recently, Xu et al. [87] have identified 3 new pentacyclic triterpenes which were elucidated to be 3-O-galloyloleanolic acid, 23-acetoxy-3-O-galloyloleanolic acid, and 3acetoxy-23-O-galloyloleanolic acid (Figure 1(a)), along with 22 compounds known from the $Q$. liaoningensis acorn which showed antidiabetic effect. Lei et al. [45] successfully isolated new triterpenoids which were identified as ursane, oleanane, and lupinane type and were found to be associated with the antineuroinflammatory activity (Figure 1(b)). In another study, ten pentacyclic triterpenes, three of which were novel, were isolated from acorns Quercus serrata var. brevipetiolata [44] (shown in Figure 1(c)).

Endo et al. [50] investigated the antitoxoplasma effect of the Quercus crispula Blume outer bark. The authors identified three pentacyclic triterpenoids, namely, 29-norlupane3,20-dione, oleanolic acid acetate, and ursolic acid acetate (Figure 2(a)) and concluded that these compounds exhibited notable activities against the Toxoplasma gondii parasite. Using HRESIMS and 1D/2D NMR experiments, Gammacurta et al. [89] screened EtOAc extracts from the Quercus petraea heartwood for phytochemical investigations and isolated eight new triterpenoids (1-8) (Figure 2(b)) and two known functionalized triterpenoids. Posteriorly, Perez et al. [90] in their study, identified 12 new triterpenoids, 1-12 (Figure 2(c)), and five known oleanane types which showed cytotoxicity activity against cancer cells (PC3 and MCF-7) and lymphocytes.

Previously, three new 24-noroleanane triterpenoids, 2a,19a-dihydroxy-3-oxo-24-norolean-12- en-28-oic acid, 19a-hydroxy-3-oxo-24-norolean-12-en-28-oic acid, and 2a,3b,19a-trihydroxy-24-norolean-12-en-28-oic acid (Figure 1(d)), were also isolated from Q. aliena var. acuteserrata, with previously known compounds (bartogenic acid, ilexgenin, and aophitolic acid) [88]. The chemical structures of the bioactive compounds of Quercus species are shown in Figure 3.

\section{Pharmacological Activities}

Traditional uses of Quercus species have led researchers to investigate their biological activities and to validate the uses of species of the genus as therapeutic remedies. Several pharmacological activities have been reported to be exhibited by extracts as well as single compounds, such as antioxidant, antibacterial, anti-inflammatory, and cytotoxicity activity. Table 3 summarizes the major bioactive compounds of Quercus species and its pharmacological activities.

5.1. Antioxidant Activity. Quercus genus has been reported to possess antioxidant activity $[41,42,69,92]$. A recent study by Arina and Harisun [93] has evaluated the effect of extraction temperatures on the tannin content and antioxidant activity of Quercus infectoria (Manjakani). According to the result, the extract gives high DPPH scavenging capacity with an IC50 value of $0.064 \mathrm{mg} / \mathrm{ml}$ at the extraction temperature of $75^{\circ} \mathrm{C}$. Another study showed that the thermotreatment and extraction technique had a determinant role in the antioxidant efficiency of Quercus cerris L. wood [94]. The antioxidant activities of leaves and acorn of $Q$. suber were investigated using 3 different solvents (hexane, methanol, and water). In this case, the aqueous extracts displayed the highest antioxidant activity, based on DPPH and ABTS assays. This antioxidant activity might be ascribed to the presence of phytochemical compounds such as phenolic compounds in the acorn extracts $[69,92]$.

Q. sideroxyla infusions have exhibited the highest antioxidant activity followed by $Q$. eduardii and Q. durifolia infusions, based on Trolox equivalent antioxidant capacity [95]. In addition, $\beta$-sitosterol-D-glucoside and condensed tannin fractions $(\mathbf{2}, \mathbf{3}, \mathbf{4}, \mathbf{5}, \mathbf{6})$ isolated from the leaves of Quercus phillyraeoides have also been studied for their antioxidant potential. The highest DPPH scavenging capacity was exhibited by fraction 5 , followed by fractions $\mathbf{3}, \mathbf{2}, \mathbf{6}$, and 4 with IC50 values of 9.34, 10.53, 10.84, 12.98, and $13.12 \mu \mathrm{g} /$ $\mathrm{ml}$, respectively [91]. Furthermore, Amessis-Ouchemoukh et al. [96] investigated the antioxidant activity of carob pods (Ceratonia siliqua), white figs (Ficus carica), and acorn (Quercus ilex). Their results showed that Quercus ilex and Ceratonia siliqua were very effective in scavenging $\mathrm{DPPH}$ and ABTS radicals, $93.93 \pm 0.13$ and $82.45 \pm 0.23 \%$ in the DPPH assay and $83.09 \pm 0.07$ and $81.51 \pm 0.12 \%$ in the ABTS assay, respectively. As expected in this research, the obtained inhibitions were better than those displayed by standards BHA, catechin, quercetin, and trolox with $26.63 \pm 0.56$, $56.09 \pm 0.24,70.43 \pm 0.15$, and $61.21 \pm 1.15 \%$, respectively. Extracts from other Quercus species have been also tested. As an example, Sánchez-Burgos et al. [46] showed that aqueous extracts obtained from the leaves of different white Quercus species (Q. grisea, Q. laeta, Q. obtusata, and Q. resinosa) exhibited high radical scavenging activity against (DPPH) and $\mathrm{HO} \bullet$ radicals. 

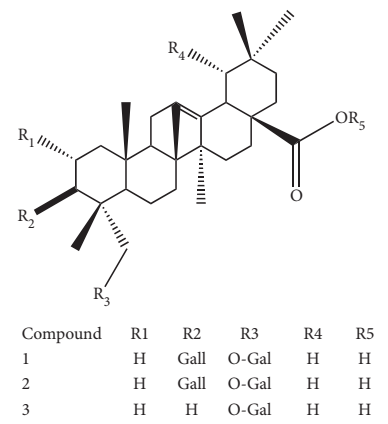

(a)
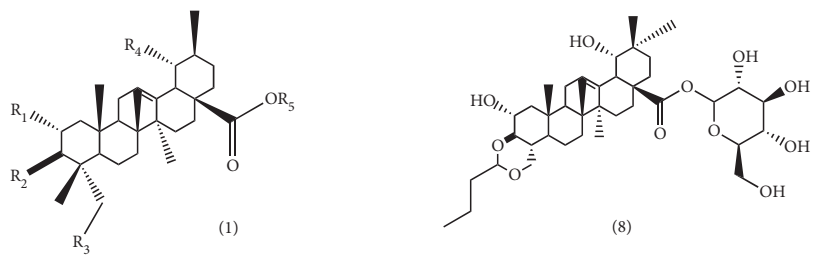

$\begin{array}{lllllll}\text { Compound } & \mathrm{R} 1 & \mathrm{R} 2 & \mathrm{R} 3 & \mathrm{R} 4 & \mathrm{R} 5\end{array}$ $\mathrm{OH} \quad \mathrm{CH}_{3} \quad \mathrm{O}-\mathrm{Gal} \quad \mathrm{OH} \quad \mathrm{Glc}$
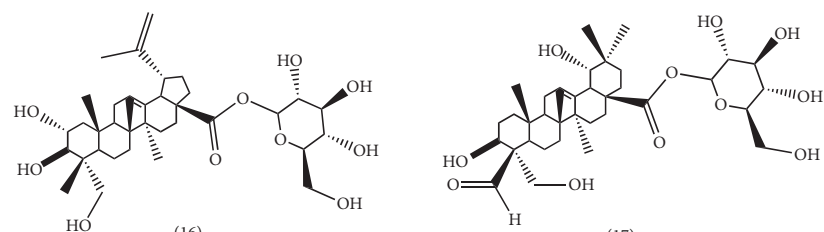

(17)

(1)-23-O-Galloyl-2a, 3ß, 19a-trihydroxyurs-12-en-28-oic acid 28-O-B-Dglucopyranoside

(8)-3, 23-O-Butylidene-2a, 3B, 19a, 23-tetrahydroxyolean-12-en-28-oic acid 28-O-B-Dglucopyranoside

(16)-2a, 3ß, 23-Trihydroxylup-20(29)-en-28-oic acid 28-O-B-Dglucopyranoside

(17)-3ß, 23-Dihydroxy-24-oxo-olean-12-en-28-oic acid 28-O-ß3-Dglucopyranoside

(b)
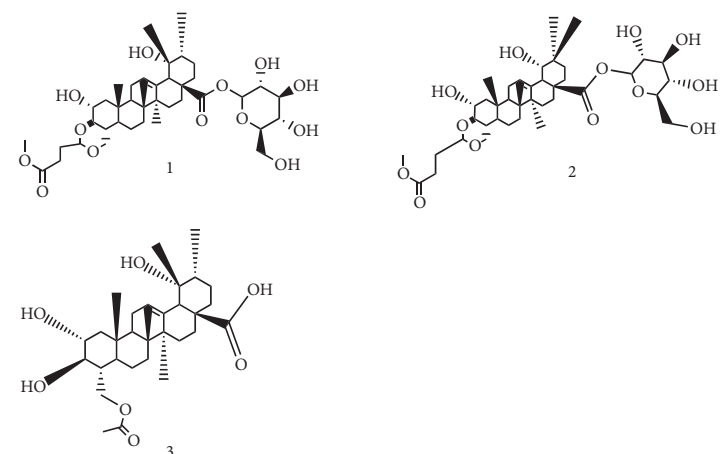

(1)-3, 23-O-methyl butyrate-2, 3, 19, 23-tetrahydroxy-urs-12-en-28-oic acid-d-glucopyranosyl ester (2)-3, 23-O-methyl butyrate-2, 3, 19, 23-tetrahydroxy-olean-12-en-28-oic acid-d-glucopyranosyl ester (3)-23-acetoxy-2, 3, 19-trihydroxyurs-12-en-28-oic acid

(c)

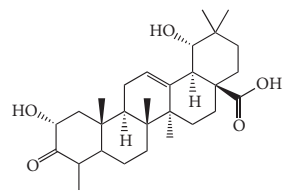

2a, 19a-dihydroxy-3-oxo-24-norolean-12-en-28-oic acid

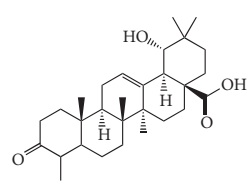

19a-hydroxy-3-oxo-24-norolean-12-en-28-oic acid

(d)

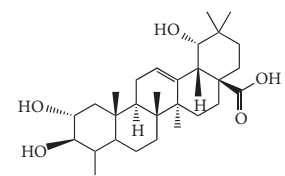

2a, 3B, 19a-trihydroxy-24-norolean-12-en-28-oic acid

Figure 1: (a) Chemical structure of the 3 new pentacyclic triterpenes which were elucidated to be 3-O-galloyloleanolic acid, 23-acetoxy-3-Ogalloyloleanolic acid, and 3-acetoxy-23-O-galloyloleanolic acid from the Q. liaotungensis acorn [49]. (b) Four new triterpenoid saponins from Q. serrata var. brevipetiolata [45]. (c) New triterpenoid saponins isolated from acorns of Q. serrata var. brevipetiolata [44]. (d) Three new 24-noroleanane triterpenoids from Q. aliena var. acuteserrata [88]. 


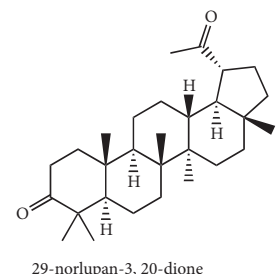

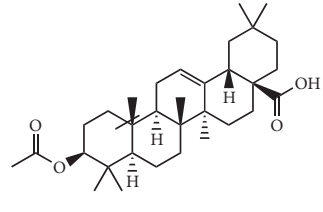

oleanolic acid acetate

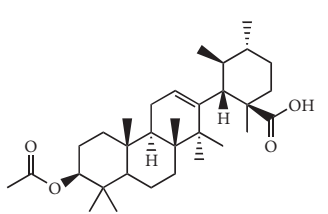

Ursolic acid acetate

(a)

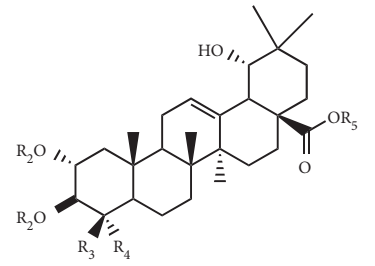<smiles>CC(=O)c1cc(O)c(O)c(O)c1</smiles><smiles>OC[C@H]1OC(O)[C@H](O)[C@H](O)[C@H]1O</smiles><smiles>O=C(O)C1C(O)C(O)C(O)C1CO</smiles>

$\begin{array}{ccc}\text { R3 } & \mathrm{R} 4 & \mathrm{R} 5 \\ \mathrm{CH}_{3} & \mathrm{CH}_{2} \mathrm{OH} & \mathrm{H} \\ \mathrm{CH}_{2} \mathrm{OG} \text { all } & \mathrm{CH}_{3} & \mathrm{H} \\ \mathrm{CH}_{2} \mathrm{OH} & \mathrm{CH}_{3} & \mathrm{H} \\ \mathrm{CH}_{2} \mathrm{OGall} & \mathrm{CH}_{3} & \mathrm{Glc} \\ \mathrm{CH}_{2} \mathrm{OH} & \mathrm{CH}_{3} & \mathrm{Glc} \\ \mathrm{CH}_{3} & \mathrm{CH}_{2} \mathrm{OH} & \mathrm{H} \\ \mathrm{CH}_{2} \mathrm{OH} & \mathrm{CH}_{3} & \mathrm{H} \\ \mathrm{CH}_{3} & \mathrm{CH}_{2} \mathrm{OH} & \mathrm{Glc}\end{array}$

(b)
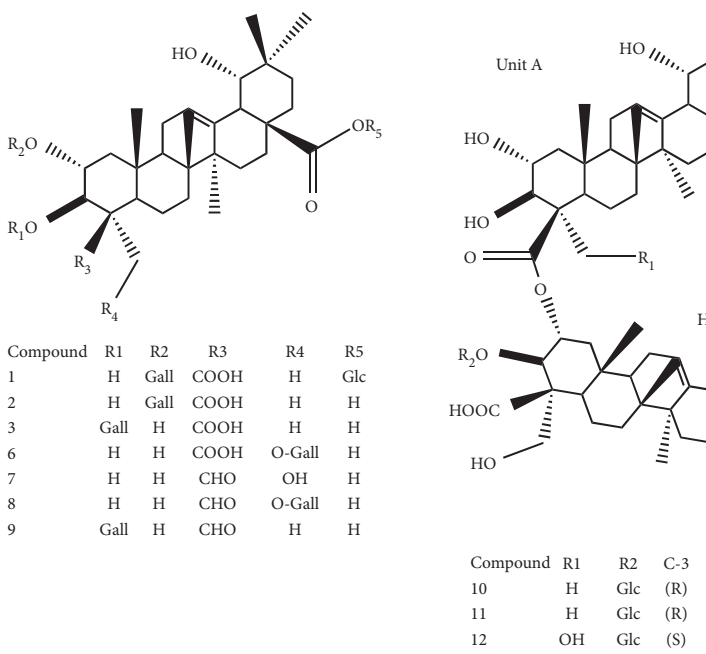

(c)

FIgURE 2: (a) Chemical structure of three pentacyclic triterpenoids isolated from the Q. crispula Blume outer bark [50]. (b) Eight new triterpenoids (1-8) isolated from Q. petraea [89]. (c) 12 new triterpenoids identified from oak heartwood Q. robur [90].

Makhlouf et al. [97] performed antioxidant activity analysis of fixed oil from three acorn species grown in Algeria: Quercus ilex L, Quercus suber L, and Quercus coccifera $\mathrm{L}$ and observed that oils methanolic extracts had remarkable antioxidant activity, up to 3.34 and $3.79 \mu \mathrm{mol}$ TE g-1 oil in the DPPH and ABTS tests, respectively.

Reported findings from different scientists illustrate that Quercus species are a good source of natural 
<smiles>OCC1OC(OC2CC(C=Cc3ccc(O)cc3)=CC(O)C2)C(O)C(O)[C@@H]1O</smiles><smiles>Oc1cc(Cl)c2c(c1)CC(O)C(c1ccc(O)c(O)c1)O2</smiles><smiles>OC1CCC(C2CC(O)C(O)CC2O)CC1O</smiles><smiles>C=C(C)C1CCC2(CO)CCC3(C)CCC4C(CCC5C(C)(C)C(O)CCC45C)C3CCC12</smiles>
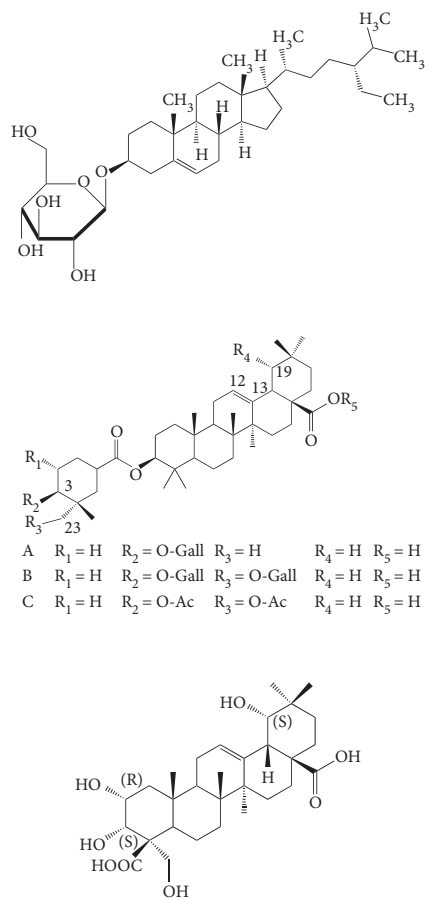

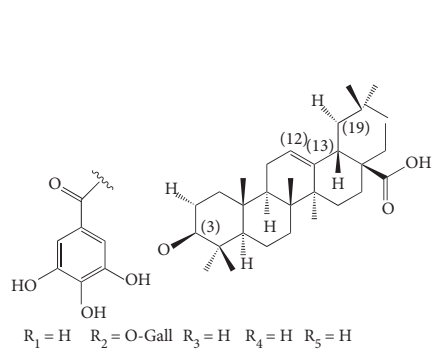

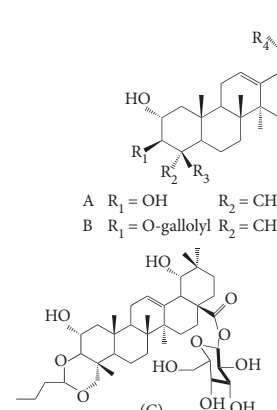

(C) $\mathrm{OH}_{\mathrm{OH}}$

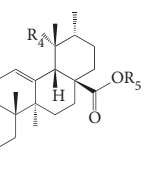

$\mathrm{R}_{3}=\mathrm{O}$-gallolyl $\mathrm{R}_{4}=\mathrm{OH} \quad \mathrm{R}_{5}=\mathrm{B}$-D-Glc $\mathrm{R}_{4}=\mathrm{OH} \quad \mathrm{R}_{5}=\mathrm{B}$-D-Glc

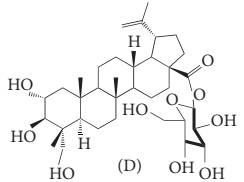

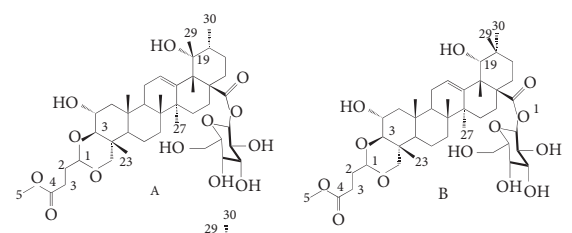
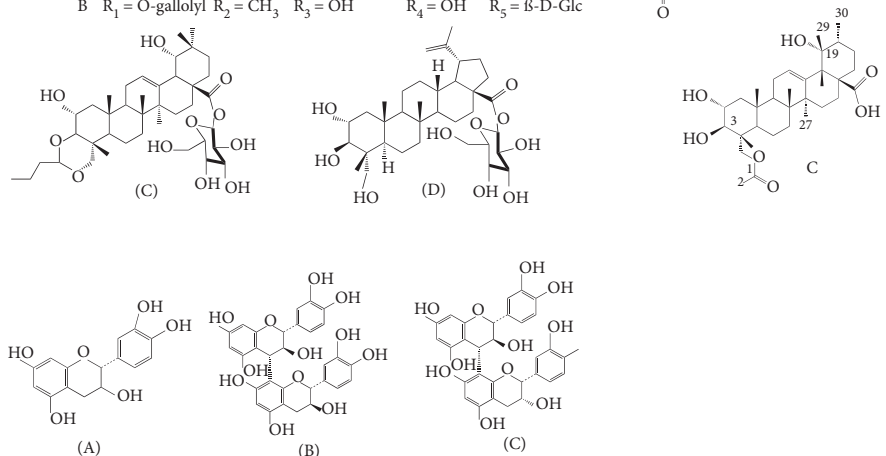

FIgURE 3: Chemical structures of bioactive compounds of Quercus species.

antioxidants which can be explored as ingredients for functional food and nutraceutical industry.

5.2. Antibacterial Activity. The antibacterial activity of Quercus has been investigated against Gram-positive and Gram-negative bacteria including multidrug-resistant bacterial pathogens. An aqueous extract of leaves from four species of white oaks ( $Q$ resinosa, $Q$ laeta, $Q$ grisea, and $Q$ obtusata) was investigated for antimicrobial activities against a range of bacteria (E. coli, S. epidermidis, $K$. pneumoniae, P. mirabilis, P. hauseri, P. vulgaris, and E. aerogenes) and yeast (C. albicans). They further reported that all aqueous extracts of oak tested showed susceptibility to K. pneumoniae (ATCC 13883). These researchers also reported that $Q$. resinosa and $Q$. grisea denoted antimitotic activity against these organisms [46], whereas Bahador and Baserisalehi [98] tested the antibacterial activity against Gram-negative bacteria (E. coli, Salmonella typhimurium, Shigella dysenteriae, and Yersinia enterocolitica) of the fruit of Q. castaneifolia. According to their finding, $S$. dysenteriae was more sensitive with a zone of inhibition of $18 \mathrm{~mm}$, and he MIC value was $2.5 \times 10^{-4}$. The lowest MIC values were found for extracts for E. coli. In a study carried out by Sarwar et al. [28], the antibacterial activity of the gold nanoparticle synthesized from the leaves of Quercus incana was evaluated against the human pathogens (Pseudomonas 
TABle 3: Biological activities of some compounds from Quercus species.

\begin{tabular}{|c|c|c|c|c|}
\hline No & Compound name & Biological activity & Description & Reference \\
\hline 1 & Polydatin & Dermatological disorders & $\begin{array}{l}\text { Showed potent tyrosinase inhibition compared to } \\
\text { the positive control, kojic acid, with an IC50 value } \\
\text { of } 4.05 \pm 0.30 \mu \mathrm{g} / \mathrm{mL}\end{array}$ & [83] \\
\hline 2 & (-)-8-Chlorocatechin & Antidiabetic & $\begin{array}{l}\text { The most potent isolate, also more potent than the } \\
\text { positive control, acarbose, with an IC50 value of } \\
\qquad 43.60 \pm 0.67 \mu \mathrm{g} / \mathrm{mL}\end{array}$ & [83] \\
\hline 3 & $\beta$-Sitosterol-D-glucoside & & $\begin{array}{c}\text { Showed moderate inhibitory activity against } \\
\alpha \text {-glucosidase }\end{array}$ & \\
\hline 4 & Tiliroside & Antidiabetic & $\begin{array}{c}\text { Highest } \alpha \text {-glucosidase inhibitory activity with an } \\
\text { IC50 of } 28.36 \pm 0.11 \mathrm{mmol} / \mathrm{L}\end{array}$ & {$[86,91]$} \\
\hline 5 & Epicatechin & Antioxidant & $\begin{array}{l}\text { Higher antioxidant activity with inhibitory } \\
\text { concentrations (IC50) of } 22.55 \pm 2.23 \mathrm{mmol} / \mathrm{L} \\
\text { than that of quercetin, which was used as the } \\
\text { standard, with an IC50 of } 28.08 \pm 2.39 \mathrm{mmol} / \mathrm{L}\end{array}$ & {$[86]$} \\
\hline 6 & $\begin{array}{c}\text { A-3-O-Galloyloleanolic acid-23- } \\
\text { acetoxy-3-O-galloyloleanolic acid } \\
\text { B-3-Acetoxy-23-O-galloyloleanolic acid } \\
\text { C-3-O-Galloylursolic acid }\end{array}$ & Antidiabetic & $\begin{array}{l}\text { Most of the compounds showed strong inhibitory } \\
\text { effects on PTP1B and } \alpha \text {-glucosidase, their IC50 } \\
\text { values were about } 6 \text {-fold to } 20 \text {-fold lower than } \\
\text { positive control }\end{array}$ & [49] \\
\hline 7 & $\begin{array}{c}\text { Quercetin-3-O-(2"-O-galloyl)- } \\
\beta \text {-galactopyranoside }\end{array}$ & Antidiabetic & $\begin{array}{l}\text { Increased the survival of pancreatic beta cells by } \\
\text { reducing the production of reactive oxygen } \\
\text { species and enhancing the activities of superoxide } \\
\text { dismutase, catalase, and glutathione in MIN6 cells } \\
\text { damaged by } \mathrm{H}_{2} \mathrm{O}_{2} \text {. The preliminary mechanism } \\
\text { by which the compound protects pancreatic beta } \\
\text { cells was through the nuclear factor erythroid-2- } \\
\text { related factor } 2\left(\mathrm{Nrf}_{2}\right) / \text { heme oxygenase-1 HO-1 } \\
\text { pathway }\end{array}$ & [87] \\
\hline 8 & Betulin & Anticancer & $\begin{array}{l}\text { Treatment with betulin increases expression of } \\
\text { the caspase family (i.e., caspase-3, -6, and -9), } \\
\text { proapoptotic genes (BAX and BAK), and } \\
\text { inhibiting antiapoptotic genes (BCL-2L1 and p53) } \\
\text { and could also regulate metastasis by inhibiting } \\
\text { MMP-2/- }\end{array}$ & [29] \\
\hline 9 & Roburgenic acid & Cytotoxicity & $\begin{array}{c}\text { Roburgenic acid was the most active compound } \\
\text { (IC50=19.7 } \mu \mathrm{M} \text { ) reaching a comparable value to } \\
\text { those of positive controls }\end{array}$ & {$[90]$} \\
\hline 10 & 3-O-Galloyloleanolic acid & $\begin{array}{l}\text { Antihepatic fibrosis and } \\
\text { antioxidant }\end{array}$ & $\begin{array}{l}\text { Upregulated the expression levels of } \mathrm{Nrf}_{2} \text { and } \\
\text { HO-1 in t-HSC/Cl-6 cells }\end{array}$ & [49] \\
\hline 11 & $\begin{array}{c}\text { A-23-O-Galloyl- } 2 \alpha, 3 \beta, 19 \alpha \text { - } \\
\text { trihydroxyurs-12-en- } 28 \text {-oic acid } 28 \text {-O- } \\
\beta \text {-D-glucopyranoside } \\
\text { B-3-O-Galloyl-2 } \alpha, 19 \alpha, 23 \text { trihydroxyurs- } \\
\text { 12-en-28-oic acid } 28 \text {-O- } \beta \text {-D- } \\
\text { glucopyranoside } \\
\text { C-3,23-O-Butylidene } 2 \alpha, 3 \beta, 19 \alpha, 23 \\
\text { tetrahydroxyolean-12-en-28-oic acid } 28 \text { - } \\
\text { O- } \beta \text {-D-glucopyranoside } \\
\text { D-2 } \alpha, 3 \beta, 23 \text {-Trihydroxylup-20(29)-en- } \\
\text { 28-oic acid } 28 \text { - O- } \beta \text {-D-glucopyranoside }\end{array}$ & Antineuroinflammatory & $\begin{array}{l}\text { The compounds reduce dose dependently the } \\
\text { expression levels of proinflammatory mediator } \\
\text { iNOS and reduce the COX-2 expression induced } \\
\text { by LPS in BV-2 cells }\end{array}$ & {$[45]$} \\
\hline 12 & $\begin{array}{l}\text { A-3,23-O-Methyl butyrate 2,3,19,23- } \\
\text { tetrahydroxy-urs-12-en-28-oic acid -d } \\
\text { glucopyranosyl ester } \\
\text { B-3,23-O-Methyl butyrate-2,3,19,23- } \\
\text { tetrahydroxy-olean-12-en-28-oic acid } \\
\text {-d-glucopyranosyl ester }\end{array}$ & Anti-inflammatory & $\begin{array}{l}\text { The three compounds showed pronounced anti- } \\
\text { inflammatory activities compared to positive } \\
\text { control indomethacin (IC50 }(\mu \mathrm{M}): 8.2 \pm 0.6 \text {, } \\
12.8 \pm 0.8,19.1 \pm 6.1 \text {, and } 47.4 \pm 4.5 \text {, respectively) } \\
\text { and higher activity against proinflammatory }\end{array}$ & {$[44]$} \\
\hline & $\begin{array}{c}\text { C-23-Acetoxy-2,3,19 trihydroxyurs-12- } \\
\text { en-28-oic acid }\end{array}$ & & cytokines (IL-6 and IL-8) & \\
\hline 13 & $\begin{array}{l}\text { A-(-)-Epicatechin } \\
\text { B-Procyanidin B3 } \\
\text { C-Procyanidin B4 }\end{array}$ & Anti-inflammatory & $\begin{array}{l}\text { The three compounds showed dose-dependent } \\
\text { inhibitory activities on gene expression of COX-2 } \\
\text { and IL- } 1 \beta\end{array}$ & {$[80]$} \\
\hline
\end{tabular}


pickettii, Salmonella setubal, Staphylococcus aureus, Bacillus subtilis, Aspergillus flavus, and Aspergillus niger). The results showed enhanced antibacterial activity against all bacterial pathogens. Besides, the ethanolic extracts of $Q$. persica have been also tested against $S$. aureus, $B$. subtilis, E. coli, and K. pneumoniae [99].

Hobby et al. [100] tested the ability to inhibit the Staphylococcus aureus biofilm using the leaf, stem, and fruit from Quercus cerris. The activity was measured using static crystal violet staining methods and confocal laser scanning microscopy. The study revealed that butanol extracts of both the leaf and stem/fruit samples were the most active, at a dose of $200 \mathrm{ug} / \mathrm{ml}$.

In an agar-well diffusion assay, the methanol and acetone extracts of the gall of $Q$. infectoria showed activity against oral pathogens such as Streptococcus mutans ATCC 25175, Porphyromonas gingivalis ATCC 33277, Streptococcus salivarius ATCC 13419, and Fusobacterium nucleatum ATCC 25586. The MIC ranged from 0.16 to $0.63 \mathrm{mg} / \mathrm{mL}$, and the most susceptible bacterium was $S$. salivarius, which suggested that the oak extract might be used against dental caries and periodontitis etiological agents [101]. In another study, the extracts of Quercus infectoria were assessed against many microbial species and used for eggshell decontamination. The antimicrobial activity was evidenced against Staphylococcus aureus, Escherichia coli, Pseudomonas aeruginosa, Salmonella typhimurium, and Candida albicans, and the results showed disinfection of eggshell microbial contamination, by immersion in 1\% QIE solution, sharply reduced total colony count, yeasts, and molds, and Enterobacteriaceae, E. coli, and S. aureus were completely inhibited after $60 \mathrm{~min}$ of immersion in QIE [102]. Another investigation demonstrated that the extract of the Quercus infectoria gall possesses antimicrobial activity against Leptospira interrogans serovar Javanica and Leptospira interrogans serovar Icterohaemorrhagiae with MIC values of $0.125 \mathrm{mg} / \mathrm{mL}$ [103].

In another work, Touati et al. [71] tested the antibacterial activity of the cork from Quercus suber L against Staphylococcus aureus ATCC, Listeria innocua, Escherichia coli, and Pseudomonas aeruginosa. The plant was collected from Algeria. The phenolic fraction of the cork was shown to inhibit the growth of $S$. aureus $(12.1 \mathrm{~mm})$ and $P$. aeruginosa $(10.07 \mathrm{~mm})$.

Therefore, different types of Quercus can be used as an alternative source of potential antimicrobial agents, and more analysis in in vivo and clinical studies is required to substantiate these in vitro findings.

5.3. Cytotoxic and Anticancer Activity. Several studies have confirmed the cytotoxic and anticancer activity of a wide variety of Quercus species extracts, against various cancer cell lines. The $\mathrm{MeOH}$ and water extracts of the barks of Quercus cerris var. cerris, Quercus macranthera subsp. syspirensis, and Quercus aucheri were subjected to the evaluation of their cytotoxicity against the Hep-2 human larynx epidermoid carcinoma cell line. The results demonstrated that aqueous and methanolic extracts of Q. macranthera subsp. syspirensis showed the strongest cytotoxicity against the tested cell line, with IC50 values $165.291 \mathrm{ug} / \mathrm{ml}$ and $273.771 \mathrm{ug} / \mathrm{ml}$, respectively [104]. In addition, the ethanolic extract of Quercus ilex has been studied for its cytotoxicity by the MTT assay in various concentrations $(250,500$, and $1000 \mathrm{mg} / \mathrm{mL})$. The results indicated that the treatment inhibited cell viability in a dose- and time-dependent manner [96].

Perez et al. [90] studied the cytotoxic activity of 17 triterpenoids isolated from oak heartwood of Quercus robur against human prostate cancer (PC3) and human estrogendependent breast adenocarcinoma (MCF-7) cell lines and lymphocytes derived from human peripheral blood. The obtained results demonstrate that breast cancer cells (MCF7) were the most affected by triterpenoids, with roburgenic acid, being the most active compound (IC50 = 19.7 $\mu \mathrm{M}$ ). The authors also reported the selectivity for some triterpenoids against lymphocytes, exhibiting an IC50>200 $\mu \mathrm{M}$, while active against cancer cells. Moreover, the genotoxicity of $Q$. resinosa leaves extracts was evaluated on HeLa cells by the single-cell electrophoresis assay (comet assay), indicating that phytochemical compounds present in extracts obtained from their decoctions increase the oxidative process and other damage to DNA in transformed human cells [47].

Recently, apoptotic and antimetastatic activities of betulin isolated from Quercus incana leaves were investigated against non-small-cell lung cancer. The results indicted significant dose-dependent induction of apoptosis after the treatment with betulin, followed by increased expression of the caspase family (i.e., caspase-3, -6, and -9), proapoptotic genes (BAX and BAK), and inhibiting antiapoptotic genes (BCL-2L1 and p53). Additionally, betulin was found to be highly and selectively active against the cancer cells at much lower doses $(11.55 \mu \mathrm{M})$ [29]. Also, it has been reported that the Quercus suber L. cork extracts induce apoptosis in human myeloid leukaemia HL-60 cells. The extracts showed a time-dependent and dose-dependent cytotoxicity in the human promyelocytic leukaemia cells [105].

Yarani et al. [106] determined the effectiveness of antiangiogenic activity of the Quercus infectoria acorn shell. Treatments showed that the extract possessed antiangiogenic potential, which exerts its inhibitory effect mainly through downregulation of essential mediators such as VEGF and MMPs.

5.4. Anti-Inflammatory and Neuroprotective Activity. Inflammation is a common pathological phenomenon respective of various diseases. The effects of Quercus species on anti-inflammation have been widely studied. MorenoJimenez et al. [95] evaluated the anti-inflammatory activity in HT-29 cells from the leaves infusion of Q. sideroxyla, Q. durifolia, and $Q$. eduardii. The results demonstrated that $Q$. sideroxyla decreased the levels of the inflammatory markers COX-2 and IL- 8 by modulating the expression of NF-Kb. Besides, studies in vitro have shown that triterpenes, isolated from acorns of Quercus serrata var. brevipetiolata, inhibit nitric oxide (NO) production and other proinflammatory cytokines [44]. Moreover, lupeol isolated from white oak leaves (Quercus resinosa, Q. grisea, Q. laeta, and Q. obtusata) was evaluated for their ability to inhibit COX-1 and COX-2 
enzymes by the in vitro colorimetric COX (ovine) inhibitor assay. In this study, lupeol from Q. obtusata demonstrated a differential effect to inhibit COX-2 without inhibiting COX1 [46]. Additionally, (-)-epicatechin, procyanidin B3, and procyanidin B4 (7) obtained from the bark of Quercus gilva Blume presented anti-inflammatory and antioxidative potency. The three compounds showed dose-dependent inhibitory activities on the gene expression of COX- 2 and IL- $1 \beta$ [80]. Studies conducted by Vázquez-Cabral et al. [107] indicate that flavonols such as quercetin glucuronide and kaempferol 3-O-glycoside are glucuronidated by the action of the kombucha consortium and that these metabolites are effective antioxidant and anti-inflammatory agents in human macrophages.

Neurodegenerative disorders are diseases that influence the nervous system, such as brain tumors, glioblastoma, epilepsy, Alzheimer's disease, and Parkinson's disease. It was reported that extracts from Quercus suber and Quercus ilex showed neuroprotective effects through inhibition of acetylcholinesterase (AChE) and butyrylcholinesterase (BChE) and protection of the human dopaminergic cell line $\mathrm{SH}-$ SY5Y [84]. Indeed, Gezici and Sekeroglu [43] reported that extracts from the shell, cup, and acorn parts of Quercus coccifera had notable $\mathrm{AChE}$ and $\mathrm{BChE}$ inhibition. Inhibitors of this enzyme are used to alleviate symptoms associated with Alzheimer's disease [84]. In another investigation, Lei et al. [45] showed potent antineuroinflammatory activity of triterpenoids isolated from Chinese acorns (Quercus serrata var. brevipetiolata), which suggested that these triterpenoids might have activities against Alzheimer's disease.

5.5. Hepatoprotective. $\mathrm{Xu}$ et al. [108] reported that acorns (Quercus liaotungensis) and their galloyl triterpenes exhibited stronger antiproliferative effects against t- $\mathrm{HSC} / \mathrm{Cl}-$ 6 cells than the reference silymarin, suggesting its potential for being developed into antihepatic fibrosis food or medicine. In the same year, Singh and Bisht [48] investigated in vivo hepatoprotective activity of the root extract of $Q$. oblongata D. DON and clearly showed the positive effect of the ethanolic extract at the dose of $300 \mathrm{mg} / \mathrm{kg}$ in comparison to the reference silymarin. Similarly, it was stated that the administration of $300 \mathrm{mg} / \mathrm{kg}$ of the Q. dilatata extract displayed protective effect against bisphenol A- (BPA-) induced hepatotoxicity by restoring hepatic inflammation towards normal [109]. Other studies performed by Toori et al. [110] investigated the hepatoprotective effects of acorn extracts on carbon tetrachloride-induced liver damage in rats. Their analyses showed that the aqueous extract at 250 and $500 \mathrm{mg}$ / $\mathrm{kg}$ displayed excellent hepatoprotective potential, indicating that this solvent is a better alternative, with no toxic effects. In addition, several studies have shown that Quercus spp. exhibited hepatoprotective effects [111].

5.6. Antidiabetic Effect. Diabetes is a chronic disease characterized by high blood glucose levels that result from the body's inability to produce insulin [112]. One promising approach for the management of diabetes is to postpone the absorption of glucose by inhibiting carbohydrate-hydrolyzing enzymes ( $\alpha$-amylase and $\alpha$-glucosidase) [85].

Custódio et al. [84] studied the inhibitory effect of leaves and acorns from Quercus suber on key enzymes relevant for hyperglycemia ( $\alpha$-amylase and $\alpha$-glucosidase). Their study showed that the best results were obtained with the water and methanol leaves extracts with values of 97 and 89\%, respectively, which could most likely be attributed to their higher phenolic content. Moreover, the extract from the bark of $Q$. coccifera exhibited stronger $\alpha$-glucosidase inhibitory activity with an IC50 value of $3.26 \pm 0.08 \mu \mathrm{g} / \mathrm{mL}$ than that reported for acarbose IC50: $50.45 \pm 0.20 \mu \mathrm{g} / \mathrm{ml}$ [83]. In another work, triterpenoids obtained from acorns of Quercus liaotungensis have been studied for their inhibitory activity against $\alpha$-glucosidase, $\alpha$-amylase, and protein-tyrosine phosphatase $1 \mathrm{~B}$. The authors found that all the compounds showed strong inhibitory effects on PTP1B and $\alpha$-glucosidase, but inhibition of $\alpha$-amylase was not observed [87]. It was also reported that the polyphenol fraction from acorn leaves (Quercus liaotungensis) inhibited $\alpha$-glucosidase and PTP1B activity [49]. Similarly, Yin et al. [85] reported that Mongolian oak cups might be a source of ellagic acid (EA), which possess prominent inhibitory activities against $\alpha$-glucosidase, $\alpha$-amylase, and formation of AGEs. Other authors reported that the chloroform extract from Quercus dilatata exhibited maximum antidiabetic activity $\alpha$-amylase inhibition of $21.61 \pm 1.53 \%$ at $200 \mu \mathrm{g} / \mathrm{ml}$ [22]. In addition, condensed tannin fractions isolated from the leaves of Quercus phillyraeoides presented potent $\alpha$-glucosidase inhibitory activities with IC50 values in the range of 2.60 to $3.14 \mu \mathrm{g} / \mathrm{ml}$, respectively [91].

Furthermore, Lin et al. [81] established that hydrolysable tannins are responsible for the lower digestibility of the acorn of Quercus fabrei Hance. These results further support the potential use of the acorn for preparation of low glycemic index foods. In a particular study, Ahmadi et al. [113] reported that prebiotics from the acorn can ameliorate HFDinduced defects in the glucose metabolism via positive modulation of the gut-microbiome-brain axis.

Gamboa-Gómez et al. [114] showed in vitro and in vivo antihyperglycemic and antioxidant effects of oak leaves infusions and fermented beverages from Quercus convallata and Q. arizonica using female C57BL/6 mice. Their results indicated that oak leaves infusions and fermented beverages exhibited exerted inhibition of $\alpha$-amylase ( $8-15 \%$ and $5-9 \%$, respectively) and $\alpha$-glucosidase (98\% and $99 \%$, respectively).

Overall, Quercus species may serve as an alternative source of potential antidiabetic agents, and more analysis in in vivo and clinical studies is required to validate these in vitro findings.

5.7. Skin Disorder. Melanin is mainly responsible for skin and hair colors. It plays an important role in protecting the skin against the harmful effects of UV radiation. However, an excessive accumulation of melanin creates various skin 
dermatological disorders like irregular skin hyperpigmentation and aesthetic problems [115]. Tyrosinase is a key enzyme in melanin biosynthesis. Inhibition of this enzyme decreases melanin production and deposition [116].

Sari et al. [83] showed that polydatin isolated from the Quercus coccifera bark displayed potent tyrosinase inhibition compared to the positive control kojic acid, with an IC50 value of $4.05 \pm 0.30 \mu \mathrm{g} / \mathrm{ml}$. In addition, Kim et al. [117] analyzed the effect of some polyamine derivatives from the bee pollen extract of $Q$. mongolica against the tyrosinase enzyme. They observed that polyamine derivatives with coumaroyl and caffeoyl moieties exhibited higher tyrosinase inhibitory potential than the others isolated with IC50 values of $19.5-85.8 \mathrm{Mm}$. Lee and coworkers [118] explored the antidermatitis effects of oak wood vinegar (OWV) in the DNCB-induced contact dermatitis mice model and showed that OWV has antiinflammatory and antiproliferative activity in a DNCBinduced contact dermatitis mice model. This activity may be linked to STAT3 inactivation.

The extract from Quercus suber leaves showed effectiveness in the prevention of photo-induced oxidative stress in the skin through scavenging multiple ROS and RNS [119]. Moreover, Koseki et al. [120] showed that the extract of Quercus acutissima Cortex inhibited androgen-related pathogenesis of acne, testosterone conversion, and sebum synthesis, partially via $5 \alpha$-reductase inhibition.

In consequence, it is possible to conclude that the Quercus species can be an important ingredient in the cosmetic product.

\section{Conclusion}

For a long time, Quercus species have been used as a traditional medicine in various countries and tribes. The bark, fruit, and leaves of the species from the genus were reported to possess a broad spectrum of biological effects, such as antioxidant, antidiabetic, anticancer, anti-inflammatory, and antibacterial. The current phytochemical studies of the species from the genus Quercus showed that phenolic acids (particularly gallic and ellagic acids and their derivatives), flavonoids (particularly flavan-3-ol), and tannins are somehow ubiquitous in all Quercus species. From these researches, phenolic compounds, triterpenoids, and flavonoids have a positive effect on anti-inflammatory, antidiabetic, and anticancer actions which can be considered as promising candidates for the development of novel pharmaceutical agents. For this, additional research on other Quercus species need much attention from biochemists for studying their detailed chemical profile and health effect, and also more studies are required to evaluate the safety, side effect, and efficacy of extracts.

\section{Abbreviations}

ATCC: American Type Culture Collection

ABTS: $\quad$ 2,2'-Azino-bis(3-ethylbenzothiazoline-6sulphonic acid)

BAX: $\quad$ Bcl-2-associated $\mathrm{X}$ protein
BAK: $\quad$ Bcl-2 antagonist/killer 1

BHT: $\quad$ Butylated hydroxytoluene

COX-1: Cyclooxygenase-1

COX-2: Cyclooxygenase-2

DPPH: 2,2-Diphenyl-1-picrylhydrazyl

FRAP: $\quad$ Ferric reducing antioxidant power

HRESIMS: High-resolution electrospray ionization mass spectrometry

QIE: Quercus infectoria extract

Q: Quercus

IL: Interleukin

iNOS: Inducible nitric oxide synthase

IC50: $\quad 50 \%$ inhibiting concentration

MBC: $\quad$ Minimum bactericidal concentration

MMPs: Matrix metalloproteinases

MIC: $\quad$ Minimum inhibitory concentration

NF-k $\beta$ : Nuclear factor kappa-light-chain-enhancer of activated B cells nitric oxide

PTP1B: $\quad$ Protein tyrosine phosphatase 1B

ROS: $\quad$ Reactive oxygen species

RNS: $\quad$ Reactive nitrogen species

STAT3: Signal transducer and activator of transcription 3

spp.: $\quad$ Plural species

UV: Ultraviolet

VEGF: Vascular endothelial growth factor.

\section{Additional Points}

(i) The medicinal uses of Quercus species are reviewed. (ii) Phenolic acids, flavonoids, and tannins are somehow ubiquitous in all Quercus species. (iii) Triterpenoids have a positive effect on anti-inflammatory and cytotoxic activity. (iv) The pharmacological aspect of extracts and pure compounds is reported.

\section{Conflicts of Interest}

The authors declare that there are no conflicts of interest.

\section{References}

[1] V. K. Bharti, J. K. Malik, and R. C. Gupta, "Ashwagandha: multiple health benefits," in Nutraceuticals, pp. 717-733, Academic Press, Cambridge, MA, USA, 2016.

[2] L. H. Tee, B. Yang, K. P. Nagendra et al., "Nutritional compositions and bioactivities of Dacryodes species: a review," Food Chemistry, vol. 165, pp. 247-255, 2014.

[3] A. F. Ismail, J. C. M. Barreira, A. S. G. Costa, and M. B. P. P. Oliveira, "A new age for Quercus spp. fruits: review on nutritional and phytochemical composition and related biological activities of acorns," Comprehensive Reviews in Food Science and Food Safety, vol. 15, no. 6, pp. 947-981, 2016.

[4] S. Valencia, "Diversidad del género Quercus (Fagaceae) en México,” Botanical Sciences, vol. 75, pp. 33-53, 2004.

[5] K. C. Nixon, "Global and geotropically distribution and diversity of oak (quercus) and oak forests," Ecology and Conservation of Montane Oak Forests, vol. 3, pp. 13-21, 2010.

[6] A. Kremer and A. L. Hipp, "Oaks: an evolutionary success story,” New Phytologist, vol. 31, pp. 630-400, 2019. 
[7] A. Romm, Botanical Medicine for Women's Health E-Book, Elsevier Health Sciences, Amsterdam, Netherlands, 2017.

[8] H. Kim, M. J. Song, and D. Potter, "Medicinal efficacy of plants utilized as temple food in traditional Korean Buddhism," Journal of Ethnopharmacology, vol. 104, no. 1-2, p. 3, 2006.

[9] H. R. Moon, M. J. Chung, J. W. Park et al., “Antiasthma effects through anti-inflammatory action of acorn (quercus Acutissimacarr.) in vitro and in vivo," Journal of Food Biochemistry, vol. 37, no. 1, pp. 108-118, 2013.

[10] M. Kim, S. H. Forouzan, E. Fazeli-Moghadam, M. RafieianKopaei, A. Adineh, and S. H. Saberianpour, "Oak (Quercus branti): an overview," Journal of Chemical and Pharmaceutical Research, vol. 7, no. 1, pp. 634-639, 2015.

[11] M. Dolatkhahi, A. Dolatkhahi, and J. B. Nejad, "Ethnobotanical study of medicinal plants used in Arjan-Parishan protected area in Fars province of Iran," Avicenna Journal of Phytomedicine, vol. 4, no. 6, p. 402, 2014.

[12] M. Mosaddegh, F. Naghibi, H. Moazzeni, A. Pirani, and S. Esmaeili, "Ethnobotanical survey of herbal remedies traditionally used in Kohghiluyeh va Boyer Ahmad province of Iran," Journal of Ethnopharmacology, vol. 141, no. 1, pp. 80-95, 2012.

[13] A. G. Pirbaloutl, "Medicinal plants used in Chaharmahal and Bakhtyari districts of Iran," Herba Polonica, vol. 55, no. 2, pp. 69-77, 2009.

[14] P. M. Guarrera, G. Forti, and S. Marignoli, "Ethnobotanical and ethnomedicinal uses of plants in the district of Acquapendente (Latium, Central Italy)," Journal of Ethnopharmacology, vol. 96, no. 3, pp. 429-444, 2005.

[15] N. Papp, S. Bartha, G. Boris, and L. Balogh, "Traditional uses of medicinal plants for respiratory diseases in Transylvania," Natural Product Communications, vol. 6, no. 10, 2011.

[16] D. Pinto, S. Diaz Franco, A. M. Silva et al., "Chemical characterization and bioactive properties of a coffee-like beverage prepared from Quercus cerris kernels," Food \& Function, vol. 10, no. 4, pp. 2050-2060, 2019.

[17] B. Sut, C. Dobeš, V. Klatte-Asselmeyer, and J. Saukel, "Ethnobotanical study on medicinal use of wild and cultivated plants in middle, south and west Bosnia and Herzegovina," Journal of Ethnopharmacology, vol. 131, no. 1, pp. 33-55, 2010.

[18] F. Tetik, S. Civelek, and U. Cakilcioglu, "Traditional uses of some medicinal plants in Malatya (Turkey)," Journal of Ethnopharmacology, vol. 146, no. 1, pp. 331-346, 2013.

[19] F. M. El-Mokasabi, "Floristic composition and traditional uses of plant species at Wadi Alkuf, Al-Jabal Al-Akhder, Libya," American-Eurasian Journal of Agricultural and Environmental Sciences, vol. 14, no. 8, pp. 685-697, 2014.

[20] M. Kargioğlu, S. Cenkci, A. Serteser, M. Konuk, and G. Vural, "Traditional uses of wild plants in the middle Aegean region of Turkey," Human Ecology, vol. 38, no. 3, pp. 429-450, 2010.

[21] J. Tardío, H. Pascual, and R. Morales, "Wild food plants traditionally used in the province of Madrid, Central Spain," Economic Botany, vol. 59, no. 2, pp. 122-136, 2005.

[22] M. Ahmed, H. Fatima, M. Qasim, and B. Gul, "Polarity directed optimization of phytochemical and in vitro biological potential of an indigenous folklore: quercus dilatata Lindl," Ex Royle. BMC Complementary and Alternative Medicine, vol. 17, no. 1, p. 386, 2017.

[23] F. Hussain, M. Islam, and A. Zaman, "Ethnobotanical profile of plants of Shawar valley, district Swat, Pakistan,"
International Journal of Biology and Biotechnology, vol. 3, no. 2, pp. 301-307, 2006.

[24] M. Jamil, B. Mirza, A. Yasmeen, and M. A. Khan, "Pharmacological activities of selected plant species and their phytochemical analysis," Journal of Medicinal Plants Research, vol. 6, no. 37, pp. 5013-5022, 2012.

[25] R. Di Novella, N. Di Novella, L. De Martino, E. Mancini, and V. De Feo, "Traditional plant use in the national park of cilento and vallo di Diano, Campania, Southern, Italy," Journal of Ethnopharmacology, vol. 145, no. 1, pp. 328-342, 2013.

[26] M. Sarri, F. Z. Mouyet, M. Benziane, and A. Cheriet, "Traditional use of medicinal plants in a city at steppic character (M'sila, Algeria)," Journal of Pharmacy and Pharmacognosy Research, vol. 2, no. 2, pp. 31-35, 2014.

[27] R. Sarwar, U. Farooq, A. Khan, S. Naz, S. Khan et al., "Evaluation of antioxidant, free radical scavenging, and antimicrobial activity of Quercus incana Roxb," Frontiers in Pharmacology, vol. 6, p. 277, 2015.

[28] R. Sarwar, U. Farooq, S. Naz, A. Khan, S. M. Bukhari, H. Khan et al., "Isolation and characterization of two new secondary metabolites from Quercus incana and their antidepressant-and anxiolytic-like potential," Frontiers in Pharmacology, vol. 9, p. 298, 2018.

[29] B. Zehra, A. Ahmed, R. Sarwar, A. Khan, U. Farooq, S. Abid Ali et al., "Apoptotic and antimetastatic activities of betulin isolated from Quercus incana against non-small cell lung cancer cells," Cancer management and research, vol. 11, pp. 1667-1683, 2019.

[30] W. Ahmad, F. Zeenat, A. Hasan, A. Abdullah, A. Nargis, and T. Tarannum, "Mazu (Quercus infectoria, Oliv)-an Overview," Indian Journal of Unani Medicine, vol. 4, no. 1, pp. 17-22, 2011.

[31] H. Hapidin, D. Rozelan, H. Abdullah, W. N. Hanaffi, and I. N. Soelaiman, "Quercus infectoria gall extract enhanced the proliferation and activity of human fetal osteoblast cell line," Malaysian Journal of Medical Sciences, vol. 22, p. 12, 2015.

[32] C. JC, A. Yusuf, S. L. Keng, S. Walluilah, F. C. Ghazali, and S. S. J. Mohsin, "Role on Quercus infectoria oliv on would healing," Malaysian Journal of Medical Sciences, vol. 14, 2007.

[33] P. S. Chauhan, S. Bisht, and S. Ahmed, "Traditional and ethnobotanical uses of medicinal trees in district Tehri Garhwal (Western Himalayas)," International Journal of Ayurvedic and Herbal Medicine, vol. 7, no. 1, pp. 2442-2448, 2017.

[34] A. K. Joshi and D. Juyal, "Traditional and ethnobotanical uses of Quercus leucotrichophora a. Camus (Quercus oblongata D. Don) in Kumaun and Garhwal regions of Uttarakhand, India: a review," International Journal of Herbal Medicine, vol. 5, pp. 06-08, 2017.

[35] B. Uniyal and V. Shiva, "Traditional knowledge on medicinal plants among rural women of the Garhwal Himalaya, Uttaranchal," Indian Journal of Traditional Knowledge, vol. 4, no. 3, pp. 259-266, 2005.

[36] J. M. Neves, C. Matos, C. Moutinho, G. Queiroz, and L. R. Gomes, "Ethnopharmacological notes about ancient uses of medicinal plants in Trás-os-Montes (northern of Portugal)," Journal of Ethnopharmacology, vol. 124, no. 2, pp. 270-283, 2009.

[37] A. Khattak, "Phytochemical evaluation, bioassay screening and aerial plant-mediated silver nanoparticles synthesis using Quercus Semecarpifolia Smith," University of Peshawar, Peshawar, Pakistan, Doctoral Dissertation, 2018. 
[38] S. Khennouf, S. Amira, L. Arrar, and A. Baghiani, "Effect of some phenolic compounds and quercus tannins on lipid peroxidation," World Applied Sciences Journal, vol. 8, no. 9, pp. 1144-1149, 2010.

[39] N. Y. Sariozlu and M. Kivanc, "Gallnuts (Quercus infectoria Oliv. and Rhus chinensis Mill.) and their usage in health," in Nuts and Seeds in Health and Disease Prevention, pp. 505-511, Academic Press, Cambridge, MA, USA, 2011.

[40] E. García-Gómez, R. Pérez-Badia, J. Pereira, and R. K. Puri, "The consumption of acorns (from quercus spp.) in the central west of the Iberian Peninsula in the 20th century," Economic Botany, vol. 71, no. 3, pp. 256-268, 2017.

[41] S. Rakić, D. Povrenović, V. Tešević, M. Simić, and R. Maletić, "Oak acorn, polyphenols and antioxidant activity in functional food," Journal of Food Engineering, vol. 74, no. 3, pp. 416-423, 2006.

[42] S. Rakić, S. Petrović, J. Kukić et al., "Influence of thermal treatment on phenolic compounds and antioxidant properties of oak acorns from Serbia," Food Chemistry, vol. 104, no. 2, pp. 830-834, 2007.

[43] S. Gezici and N. Sekeroglu, "Neuroprotective potential and phytochemical composition of acorn fruits," Industrial Crops and Products, vol. 128, pp. 13-17, 2019.

[44] J. Huang, Y. Wang, C. Li, X. Wang, and X. He, “Triterpenes isolated from acorns of Quercus serrata var. brevipetiolata exert anti-inflammatory activity," Industrial Crops and Products, vol. 91, pp. 302-309, 2016.

[45] Y. Lei, Y. Huang, Y. Wang, and X. He, "Potential antineuroinflammatory triterpenoids isolated from Chinese acorns (Quercus serrata var. brevipetiolata)," Journal of Functional Foods, vol. 50, pp. 18-25, 2018.

[46] J. A. Sánchez-Burgos, M. V. Ramírez-Mares, M. M. Larrosa et al., "Antioxidant, antimicrobial, antitopoisomerase and gastroprotective effect of herbal infusions from four Quercus species," Industrial Crops and Products, vol. 42, pp. 57-62, 2013.

[47] N. E. Rocha-Guzmán, J. A. Gallegos-Infante, R. F. GonzálezLaredo et al., "Antioxidant activity and genotoxic effect on HeLa cells of phenolic compounds from infusions of Quercus resinosa leaves," Food Chemistry, vol. 115, no. 4, pp. 1320-1325, 2009.

[48] A. Medina-Torres and M. Bisht, "Evaluation of in-vitro antioxidant potential and in-vivo hepatoprotective activity of root extract of Quercus oblongata D. DON," Journal of Drug Delivery and Therapeutics, vol. 8, no. 5-s, pp. 152-161, 2018.

[49] J. Xu, J. Cao, J. Yue, X. Zhang, and Y. Zhao, "New triterpenoids from acorns of Quercus liaotungensis and their inhibitory activity against $\alpha$-glucosidase, $\alpha$-amylase and protein-tyrosine phosphatase 1B," Journal of Functional Foods, vol. 41, pp. 232-239, 2018.

[50] M. Endo, K. Shigetomi, S. Mitsuhashi, M. Igarashi, and M. Ubukata, "Isolation, structure determination and structure-activity relationship of anti-toxoplasma triterpenoids from Quercus crispula Blume outer bark," Journal of Wood Science, vol. 65, no. 1, p. 3, 2019.

[51] A. Karimi and M. T. Moradi, "Total phenolic compounds and in vitro antioxidant potential of crude methanol extract and the correspond fractions of Quercus brantii L. acorn," Journals of Herbmed Pharmacology, vol. 4, no. 1, pp. 35-39, 2015.

[52] A. F. Vinha, A. S. G. Costa, J. C. M. Barreira, R. Pacheco, and M. B. P. P. Oliveira, "Chemical and antioxidant profiles of acorn tissues from Quercus spp.: potential as new industrial raw materials," Industrial Crops and Products, vol. 94, pp. 143-151, 2016.

[53] J. P. Silva, A. C. Gomes, and O. P. Coutinho, "Oxidative DNA damage protection and repair by polyphenolic compounds in PC12 cells," European Journal of Pharmacology, vol. 601, no. 1-3, pp. 50-60, 2008.

[54] P. S. Manos and A. M. Stanford, "The historical biogeography of Fagaceae: tracking the tertiary history of temperate and subtropical forests of the northern hemisphere," International Journal of Plant Sciences, vol. 162, no. S6, pp. S77-S93, 2001.

[55] R. B. Kaul and C. A. Abbe, "Inflorescence architecture and evolution in the Fagaceae," Journal of the Arnold Arboretum, vol. 65, pp. 375-401, 1984.

[56] G. Uddin and A. Rauf, "Phytochemical screening, antimicrobial and antioxidant activities of aerial parts of Quercus robur L." Middle-East Journal of Medicinal Plants Research, vol. 1, no. 1, pp. 1-4, 2012.

[57] A. Aslani, S. Emami, A. Ghannadi, and M. Ajdari, "Formulation and physicochemical evaluation of an herbal antihemorrohid ointment from Quercus, black cumin and Fenugreek for the treatment of internal anal hemorrhoids," Journal of Pharmaceutical Sciences, vol. 14, pp. 247-257, 2009.

[58] M. L. Leporatti and S. Ivancheva, "Preliminary comparative analysis of medicinal plants used in the traditional medicine of Bulgaria and Italy," Journal of Ethnopharmacology, vol. 87, no. 2-3, pp. 123-142, 2003.

[59] L. M. McCune and T. Johns, "Antioxidant activity relates to plant part, life form and growing condition in some diabetes remedies," Journal of Ethnopharmacology, vol. 112, no. 3, pp. 461-469, 2007.

[60] A. R. McCutcheon, S. M. Ellis, R. E. W. Hancock, and G. H. N. Towers, "Antibiotic screening of medicinal plants of the British Columbian native peoples," Journal of Ethnopharmacology, vol. 37, no. 3, pp. 213-223, 1992.

[61] A. L. Adonizio, K. Downum, B. C. Bennett, and K. Mathee, "Anti-quorum sensing activity of medicinal plants in southern Florida," Journal of Ethnopharmacology, vol. 105, no. 3, pp. 427-435, 2006.

[62] V. S. Rawat, "Medicinal plants and sustainable livelihood in Pauri district of Garhwal Himalaya, Uttarakhand, India," International Journal of Bioassays, vol. 5, no. 06, pp. 45894592, 2016.

[63] E. Ahmed, M. Arshad, M. Ahmad, M. Saeed, and M. Ishaque, "Ethnopharmacological survey of some medicinally important plants of Galliyat areas of NWFP, Pakistan," Asian Journal of Plant Sciences, vol. 3, no. 4, pp. 410-415, 2004.

[64] J.-i. Kim, H.-h. Kim, S. Kim, K.-t. Lee, I.-h. Ham, and W.-K. Whang, "Antioxidative compounds from Quercus salicina blume stem," Archives of Pharmacal Research, vol. 31, no. 3, pp. 274-278, 2008.

[65] D. A. Bainbridge, "Use of acorns for food in California: past, present, future," in Proceedings of the Symposium o MultipleUse Management of California's Hardwood Resources, pp. 12-14, San Luis Obispo, CA, USA, November 1986.

[66] D. Pérez, "La Bellota. Alimento de humanos," Avnia, vol. 17, pp. 106-112, 2007.

[67] J. J. Kim, B. K. Ghimire, H. C. Shin et al., "Comparison of phenolic compounds content in indeciduous Quercus species," Journal of Medicinal Plants Research, vol. 6, no. 39, pp. 5228-5239, 2012.

[68] R. García-Villalba, J. C. Espín, F. A. Tomás-Barberán, and N. E. Rocha-Guzmán, "Comprehensive characterization by 
LC-DAD-MS/MS of the phenolic composition of seven Quercus leaf teas," Journal of Food Composition and Analysis, vol. 63, pp. 38-46, 2017.

[69] E. Cantos, J. C. Espín, C. López-Bote, L. de la Hoz, J. A. Ordóñez, and F. A. Tomás-Barberán, "Phenolic compounds and fatty acids from acorns (quercusspp.), the main dietary constituent of free-ranged iberian pigs," Journal of Agricultural and Food Chemistry, vol. 51, no. 21, pp. 62486255, 2003.

[70] A. M. Martínez-Gil, E. Cadahía, B. Fernández de Simón, G. Gutiérrez-Gamboa, I. Nevares, and M. del Álamo-Sanza, "Quercus humboldtii (Colombian Oak): characterisation of wood phenolic composition with respect to traditional oak wood used in oenology," Ciência e Técnica Vitivinícola, vol. 32, no. 2, pp. 93-101, 2018.

[71] R. Touati, S. A. O. Santos, S. M. Rocha, K. Belhamel, and A. J. D. Silvestre, “The potential of cork from Quercus suber L. grown in Algeria as a source of bioactive lipophilic and phenolic compounds," Industrial Crops and Products, vol. 76, pp. 936-945, 2015.

[72] B. Zhang, J. Cai, C.-Q. Duan, M. Reeves, and F. He, "A review of polyphenolics in oak woods," International Journal of Molecular Sciences, vol. 16, no. 12, pp. 6978-7014, 2015.

[73] S. A. O. Santos, P. C. R. O. Pinto, A. J. D. Silvestre, and C. P. Neto, "Chemical composition and antioxidant activity of phenolic extracts of cork from Quercus suber L." Industrial Crops and Products, vol. 31, no. 3, pp. 521-526, 2010.

[74] C. T. Yarnes, W. J. Boecklen, K. Tuominen, and J.-P. Salminen, "Defining phytochemical phenotypes: size and shape analysis of phenolic compounds in oaks (Fagaceae, Quercus) of the Chihuahuan Desert," Canadian Journal of Botany, vol. 84, no. 8, pp. 1233-1248, 2006.

[75] E. Conde, E. Cadahía, M. C. García-Vallejo, B. Fernández de Simón, and J. R. González Adrados, "Low molecular weight polyphenols in cork of Quercus suber," Journal of Agricultural and Food Chemistry, vol. 45, no. 7, pp. 2695-2700, 1997.

[76] P. C. R. O. Pinto, A. F. Sousa, A. J. D. Silvestre et al., "Quercus suber and Betula pendula outer barks as renewable sources of oleochemicals: a comparative study," Industrial Crops and Products, vol. 29, no. 1, pp. 126-132, 2009.

[77] Y. Kamano, Y. Tachi, T. Otake, and M. Komatsu, "Studies on the constituents of quercus spp. III.: on the constituents of quercus stenophylla MAKINO," Yakugaku Zasshi, vol. 89, no. 9, pp. 1302-1305, 1969.

[78] F. Gul, K. M. Khan, A. Adhikari et al., "Antimicrobial and antioxidant activities of a new metabolite from Quercus incana," Natural Product Research, vol. 31, no. 16, pp. 1901-1909, 2017.

[79] N. E. Rocha-Guzmán, R. F. González-Laredo, B. D. VázquezCabral et al., "Oak leaves as a new potential source for functional beverages: their antioxidant capacity and monomer flavonoid composition," in Functional and Medicinal Beverages, pp. 381-411, Academic Press, Cambridge, MA, USA, 2019.

[80] S. H. Youn, J. H. Kwon, J. Yin et al., "Anti-inflammatory and anti-urolithiasis effects of polyphenolic compounds from quercus gilva blume," Molecules, vol. 22, no. 7, p. 1121, 2017.

[81] Y. Lin, Y. Lu, Z. Song, and D. Huang, "Characterizations of the endogenous starch hydrolase inhibitors in acorns of Quercus fabri hance," Food Chemistry, vol. 258, pp. 111-117, 2018.

[82] R. Brossa, I. Casals, M. Pintó-Marijuan, and I. Fleck, "Leaf flavonoid content in Quercus ilex L. resprouts and its seasonal variation," Trees, vol. 23, no. 2, pp. 401-408, 2009.
[83] S. Sari, B. Barut, A. Özel, A. Kuruüzüm-Uz, and D. Şöhretoğlu, "Tyrosinase and $\alpha$-glucosidase inhibitory potential of compounds isolated from Quercus coccifera bark: in vitro and in silico perspectives," Bioorganic Chemistry, vol. 86, pp. 296-304, 2019.

[84] L. Custódio, J. Patarra, F. Alberício, N. d. R. Neng, J. M. F. Nogueira, and A. Romano, "Phenolic composition, antioxidant potential and in vitro inhibitory activity of leaves and acorns of Quercus suber on key enzymes relevant for hyperglycemia and Alzheimer's disease," Industrial Crops and Products, vol. 64, pp. 45-51, 2015.

[85] P. Yin, L. Yang, Q. Xue et al., "Identification and inhibitory activities of ellagic acid- and kaempferol-derivatives from Mongolian oak cups against $\alpha$-glucosidase, $\alpha$-amylase and protein glycation linked to type II diabetes and its complications and their influence on HepG2 cells' viability," Arabian Journal of Chemistry, vol. 11, no. 8, pp. 1247-1259, 2018.

[86] A. W. Indrianingsih, S. Tachibana, R. T. Dewi, and K. Itoh, "Antioxidant and $\alpha$-glucosidase inhibitor activities of natural compounds isolated from Quercus gilva Blume leaves," Asian Pacific Journal of Tropical Biomedicine, vol. 5, no. 9, pp. 748-755, 2015.

[87] J. Xu, X. Wang, J. Yue, Y. Sun, X. Zhang, and Y. Zhao, "Polyphenols from acorn leaves (quercus liaotungensis) protect pancreatic beta cells and their inhibitory activity against $\alpha$-glucosidase and protein tyrosine phosphatase $1 \mathrm{~B}$," Molecules, vol. 23, no. 9, p. 2167, 2018.

[88] H.-D. Chen, S.-P. Yang, S.-G. Liao, C.-R. Zhang, and J.-M. Yue, "Three new 24-noroleanane triterpenoids from Quercus aliena var. acuteserrata," Helvetica Chimica Acta, vol. 89, no. 9, pp. 1971-1977, 2006.

[89] M. Stochmal, P. Waffo-Teguo, D. Winstel et al., “Triterpenoids from quercus petraea: identification in wines and spirits and sensory assessment," Journal of Natural Products, vol. 82, no. 2, pp. 265-275, 2019.

[90] A. J. Pérez, Ł. Pecio, M. Kowalczyk et al., "Triterpenoid components from oak heartwood (quercus robur) and their potential health benefits," Journal of Agricultural and Food Chemistry, vol. 65, no. 23, pp. 4611-4623, 2017.

[91] A. W. Indrianingsih and S. Tachibana, "Bioactive constituents from the leaves of Quercus phillyraeoides A. Gray for $\alpha$-glucosidase inhibitor activity with concurrent antioxidant activity," Food Science and Human Wellness, vol. 5, no. 2, pp. 85-94, 2016.

[92] D. Tejerina, S. García-Torres, M. Cabeza de Vaca, F. M. Vázquez, and R. Cava, "Acorns (Quercus rotundifolia Lam.) and grass as natural sources of antioxidants and fatty acids in the "montanera" feeding of Iberian pig: intra- and inter-annual variations," Food Chemistry, vol. 124, no. 3, pp. 997-1004, 2011.

[93] M. I. Arina and Y. Harisun, "Effect of extraction temperatures on tannin content and antioxidant activity of Quercus infectoria (Manjakani)," Biocatalysis and Agricultural Biotechnology, vol. 19, Article ID 101104, 2019.

[94] P. Cetera, D. Russo, L. Milella, and L. Todaro, "Thermotreatment affects Quercus cerris L. wood properties and the antioxidant activity and chemical composition of its byproduct extracts," Industrial Crops and Products, vol. 130, pp. 380-388, 2019.

[95] M. R. Moreno-Jimenez, F. Trujillo-Esquivel, M. A. GallegosCorona et al., "Antioxidant, anti-inflammatory and anticarcinogenic activities of edible red oak (Quercus spp.) infusions in rat colon carcinogenesis induced by 1,2- 
dimethylhydrazine," Food and Chemical Toxicology, vol. 80, pp. 144-153, 2015.

[96] N. Ramos-Gomez, S. Ouchemoukh, N. Meziant et al., "metabolites involved in the antioxidant, anticancer and anticalpain activities of Ficus carica L., Ceratonia siliqua L. and Quercus ilex L. extracts," Industrial Crops and Products, vol. 95, pp. 6-17, 2017.

[97] F. Z. Madani, G. Squeo, M. Barkat, A. Trani, and F. Caponio, "Antioxidant activity, tocopherols and polyphenols of acornoil obtained from Quercus species grown in Algeria," Food Research International, vol. 114, pp. 208-213, 2018.

[98] N. Bahador and M. Baserisalehi, "The effect of Quercus castaneifolia extract on pathogenic enteric bacteria," $A n$ aerobe, vol. 17, no. 6, pp. 358-360, 2011.

[99] H. Nourafcan, M. Nasrollahpour, and I. Bajalan, "Antibacterial activity of leaves extract from oak (Quercus persica) against some positive and negative bacteria," International Journal of Farming and Allied Sciences, vol. 2, no. 24, pp. 1153-1155, 2013.

[100] G. H. Hobby, C. L. Quave, K. Nelson, C. M. Compadre, K. E. Beenken, and M. S. Smeltzer, "Quercus cerris extracts limit Staphylococcus aureus biofilm formation," Journal of Ethnopharmacology, vol. 144, no. 3, pp. 812-815, 2012.

[101] S. Patel, A. Rauf, and H. Khan, "The relevance of folkloric usage of plant galls as medicines: finding the scientific rationale," Biomedicine \& Pharmacotherapy, vol. 97, pp. 240247, 2018.

[102] A. A. Tayel, M. A. El-Sedfy, A. I. Ibrahim, and S. H. Moussa, "Application of Quercus infectoria extract as a natural antimicrobial agent for chicken egg decontamination," Revista Argentina de Microbiología, vol. 50, no. 4, pp. 391-397, 2018.

[103] H. Mustafa, N. Ismail, and W. N. A. Wahab, "Anti-microbial activity of aqueous quercus infectoria gall extract against pathogenic Leptospira," Malaysian Journal of Medical Sciences, vol. 25, no. 4, pp. 42-50, 2018.

[104] D. Wan Abdul Wahab, S. Sabuncuoğlu, and Ü. Ş. Harput, "Evaluation of antioxidative, protective effect against $\mathrm{H}_{2} \mathrm{O}_{2}$ induced cytotoxicity, and cytotoxic activities of three different Quercus species," Food and Chemical Toxicology, vol. 50, no. 2, pp. 141-146, 2012.

[105] I. Bejarano, B. Godoy-Cancho, L. Franco, M. A. MartínezCañas, and M. A. Tormo, "Quercus SuberL. Cork extracts Induce apoptosis in human myeloid leukaemia HL-60 cells," Phytotherapy Research, vol. 29, no. 8, pp. 1180-1187, 2015.

[106] R. Yarani, K. Mansouri, H. R. Mohammadi-Motlagh, A. Mahnam, and M. S. Emami Aleagha, "In vitroinhibition of angiogenesis by hydroalcoholic extract of oak (Quercus infectoria) acorn shell via suppressing VEGF, MMP-2, and MMP-9 secretion," Pharmaceutical Biology, vol. 51, no. 3, pp. 361-368, 2013.

[107] B. D. Vázquez-Cabral, M. Larrosa-Pérez, J. A. GallegosInfante et al., "Oak kombucha protects against oxidative stress and inflammatory processes," Chemico-Biological Interactions, vol. 272, pp. 1-9, 2017.

[108] J. Rocha-Guzmán, X. Wang, G. Su et al., "The antioxidant and anti-hepatic fibrosis activities of acorns (Quercus liaotungensis) and their natural galloyl triterpenes," Journal of Functional Foods, vol. 46, pp. 567-578, 2018.

[109] S. T. B. Zhao, M. Majid, S. Maryam et al., "Quercus dilatata Lindl. ex royle ameliorates BPA induced hepatotoxicity in Sprague Dawley rats," Biomedicine \& Pharmacotherapy, vol. 102, pp. 728-738, 2018.

[110] M. A. Toori, M. Mirzaei, N. Mirzaei, P. Lamrood, and A. Mirzaei, "Antioxidant and hepatoprotective effects of the internal layer of oak fruit (Jaft)," Journal of Medicinal Plant Research, vol. 7, pp. 24-28, 2013.

[111] M. Naim, W. Begum, and F. Shakoor, "Quercus infectoria (Mazu): a review," World Journal of Pharmaceutical Research, vol. 6, pp. 176-185, 2017.

[112] C. Triplitt, C. Solis-Herrera, E. Cersosimo, M. Abdul-Ghani, and R. A. Defronzo, "Empagliflozin and linagliptin combination therapy for treatment of patients with type 2 diabetes mellitus," Expert Opinion on Pharmacotherapy, vol. 16, no. 18, pp. 2819-2833, 2015.

[113] S. Ahmadi, R. Nagpal, S. Wang et al., "Prebiotics from acorn and sago prevent high-fat-diet-induced insulin resistance via microbiome-gut-brain axis modulation," The Journal of Nutritional Biochemistry, vol. 67, pp. 1-13, 2019.

[114] C. I. Yadav, L. E. Simental-Mendía, R. F. González-Laredo et al., "In vitro and in vivo assessment of anti-hyperglycemic and antioxidant effects of Oak leaves (Quercus convallata and Quercus arizonica) infusions and fermented beverages," Food Research International, vol. 102, pp. 690-699, 2017.

[115] S. Rocha-Guzmán, E. Camera, and M. Picardo, "Chemical and instrumental approaches to treat hyperpigmentation," Pigment Cell Research, vol. 16, no. 2, pp. 101-110, 2003.

[116] C. Carriço, H. M. Ribeiro, and J. Marto, "Converting cork byproducts to ecofriendly cork bioactive ingredients: novel pharmaceutical and cosmetics applications," Industrial Crops and Products, vol. 125, pp. 72-84, 2018.

[117] S. B. Kim, Q. Liu, J. H. Ahn et al., "Polyamine derivatives from the bee pollen of Quercus mongolica with tyrosinase inhibitory activity," Bioorganic Chemistry, vol. 81, pp. 127133,2018

[118] C. S. Lee, E. H. Yi, H.-R. Kim et al., “Anti-dermatitis effects of oak wood vinegar on the DNCB-induced contact hypersensitivity via STAT3 suppression," Journal of Ethnopharmacology, vol. 135, no. 3, pp. 747-753, 2011.

[119] I. F. Almeida, E. Fernandes, J. L. F. C. Lima, P. C. Costa, and M. F. Bahia, "Protective effect of Castanea sativa and Quercus robur leaf extracts against oxygen and nitrogen reactive species," Journal of Photochemistry and Photobiology B: Biology, vol. 91, no. 2-3, pp. 87-95, 2008.

[120] J. Koseki, T. Matsumoto, Y. Matsubara et al., "Inhibition of rat $5 \alpha$-reductase activity and testosterone-induced sebum synthesis in hamster sebocytes by an extract of Quercus acutissima cortex," Evidence-Based Complementary and Alternative Medicine, vol. 2015, Article ID 853846, 9 pages, 2015. 